\title{
De plaats van de rechter in het staatsbestel : enige beschouwingen over de positie van de rechter ten opzichte van wetgever en bestuur, toegespitst op het vraagstuk van de constitutionele rechtspraak
}

Citation for published version (APA):

Stroink, F. A. M. (1990). De plaats van de rechter in het staatsbestel : enige beschouwingen over de positie van de rechter ten opzichte van wetgever en bestuur, toegespitst op het vraagstuk van de constitutionele rechtspraak. W.E.J. Tjeenk Willink. https://doi.org/10.26481/spe.19900208fs

Document status and date:

Published: 08/02/1990

DOI:

$10.26481 /$ spe.19900208fs

Document Version:

Publisher's PDF, also known as Version of record

Please check the document version of this publication:

- A submitted manuscript is the version of the article upon submission and before peer-review. There can be important differences between the submitted version and the official published version of record. People interested in the research are advised to contact the author for the final version of the publication, or visit the DOI to the publisher's website.

- The final author version and the galley proof are versions of the publication after peer review.

- The final published version features the final layout of the paper including the volume, issue and page numbers.

Link to publication

\footnotetext{
General rights rights.

- You may freely distribute the URL identifying the publication in the public portal. please follow below link for the End User Agreement:

www.umlib.nl/taverne-license

Take down policy

If you believe that this document breaches copyright please contact us at:

repository@maastrichtuniversity.nl

providing details and we will investigate your claim.
}

Copyright and moral rights for the publications made accessible in the public portal are retained by the authors and/or other copyright owners and it is a condition of accessing publications that users recognise and abide by the legal requirements associated with these

- Users may download and print one copy of any publication from the public portal for the purpose of private study or research.

- You may not further distribute the material or use it for any profit-making activity or commercial gain

If the publication is distributed under the terms of Article $25 \mathrm{fa}$ of the Dutch Copyright Act, indicated by the "Taverne" license above,

Download date: 26 Apr. 2023 
DE PLAATS VAN DE RECHTER

IN HET STAATSBESTEL 



\section{DE PLAATS VAN DE RECHTER IN HET STAATSBESTEL}

Enige beschouwingen over de positie van de rechter ten opzichte van wetgever en bestuur, toegespitst op het vraagstuk van de constitutionele rechtspraak

\section{REDE}

uitgesproken bij de aanvaarding van het ambt van gewoon hoogleraar in het recht, in het bijzonder in het staats- en bestuursrecht aan de

Rijksuniversiteit Limburg op donderdag 8 februari 1990

door

MR. F.A.M. STROINK

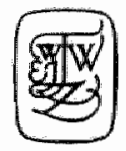

W.E.J. TJEENK WILLINK ZWOLLE 1990 


\section{F.A.M. Stroink, Amstenrade}

Alle rechten woorbehouden. Niets uit deze uitgave mag worden verveel woudigd, opgeslagen in een geautomatiseend gegevensbestand, of openbaar gemaakt, in enige vorm of op enige wijze, hetzij elekttonisch, mechanisch, door fotokopië̈n, opnamen of enige andere manier; zonder voorafgande schriftelijke toestemming van uitgeverij W.E.J. Tjeenk Willink te Zwolle.

Voor zover het maken van kopieën uit deze uitgave is toegestaan op grond van ari. $16 \mathrm{~B}$ Auteurswet 1912 jo. het Besluit van 20 juni 1974, Stb. 351 , zoals gewijzigd bij Besluit van 23 aug. 1985, Stb. $47 \mathrm{I}$ en art. 17 Auteurswet 1912, dient men de daarvoor wettelijk verschul. digde vergoedingen te voldoen aan de Stichting Reprorecht (Postbus $882,1180 \mathrm{AW}$ Amstelveen). Voor hel ovememen van gedeelte(n) uit deze uitgave in bloemlezingen, readers an andere compilatiewerken (art. 16 Auteurswet 1912) dient men zich tot de uiggever te wenderi.

No part of this book may be reproduced in any form, by print, photoprint, mic rohim or any other means without writen permission from the publisher.

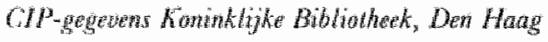

Stroink, F.A.M.

De plats van de rechter in thet statsbestel: enige beschouwingen over de positie wan de rechter ten opzichte van wetgever en bestuur, toegespitst op het waagstulk van de consitutionele rechrspraak / F.A.M. Stroink. - Zwolle: W.E.J. Tjeenk Willink Inaugurele rede Masasticht.

ISBN $90-27 \rrbracket-3153-8$

SLSO 393.71 UDC $347.962(492)(043.5)$ NUGI 693

"Trefw, rechters; Nederland. 


\section{INLEIDING}

Zeer gewaardeerde toehoorders,

Op 11 augustus 1988 deed de president van de rechtbank te Den Haageen opzienbarende uitspraak. ${ }^{2}$ Hij verbood de staat toepassing van een aantal artikelen van de Wet op het wetenschappelijk onderwijs, de Wet op het hoger beroepsonderwijs, de Wet op de Open Universiteit en de Wet op de studiefinanciering (Harmonisatiewet collegegelden).

Het toepassingsverbod had betrekking op de eisende studenten en diegenen die in het studiejaar 1987-1988 reeds als student aan een instelling van wetenschappelijk onderwijs of hoger beroepsonderwijs dan wel aan de Open Universiteit waren ingeschreven en voor wie geldt, dat hun eerder binnen het hoger onderwijs genoten onderwijsjaren (of delen van jaren) door de inwerkingtreding van de genoemde artikelen wel meetellen voor de berekening van de maximale inschrijvingsduur, terwijl deze jaren (of delen van jaren) onder de oude wetgeving niet zouden meetellen.

De uitspraak van de president is juridisch opzienbarend. Hij verbood de toepassing van een aantal artikelen van formele wetten, omdat hij wan mening was dat de rechter formele wetsbepalingen mag toetsen aan het Statuut voor het Koninkrijk der Nederlanden, in casu aan artikel 43 van dat statuut, dat in het eerste lid bepaalt dat elk der landen zorg draagt voor de verwezenlijking van de fundamentele menselijke rechten en vrijheden, de rechtszekerheid en de deugdelijkheid van het besturur. De president. achtte de desbetreffende wetsbepalingen in strijd met de rechtszekerheid.

De president is 'teruggefloten' door de Hoge Raad (HR) op 14 april 1989. ${ }^{3}$ De HR beantwoordde de vraag of de rechter de wet mag toetsen aan het Statuut ontkemnend. De Hoge Raad merkte echter wel in een terzijde op dat hij de te dezen bestreden bepalingen van de zogenaamde Harmoni-

1. De tekst van deze oratie is begin september 1989 afgerond. Met nadien verschener publikaties is in beperkte mate rekening gehouden.

2. AB, 1988, 470. Zie hierover onder meer E.A. Alkema, Het Statuut of een statuut van toetsing van de wet?, NJCM-bul. 1988, p. 615 e.w.; C.A.J.M. Kortmann, De rechter en de wel, RegelMaat 1988, p. 135 e. $;$; C. Flinterman, Hel Statut getoetst, Publiek Domein 1988 , p. 53 e.v. R. H. de Winter, Nota Bene, Publiek Domein 1988, p. 64-65; R. M. van Malle; Toesing van wetgeving (LSVB-Stat), AA 1998, p. 776 e.v.; Henc van Marseven, Toetsen

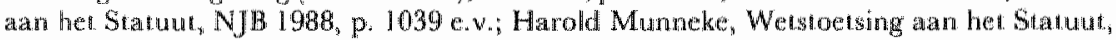
NJB 1988, p. 1043 .

Zie voor de reactie van de minister op deze witspraak TK 1988-1989, 20469, no. 29 . De minister deelt mee te zullen bevorderen datt. de materide strekking van her vonnis in kort geding wordt gecontinueerd voor twoe studiejaren: $1989-1990$ en 1990 -1991.

3. AB, 1989, 207 m.ni. FHudB, AA 1989 , p. 578 e.v. m.nt E.M.H. Hirsch Ballin; RegelMata 1989, p. 80 e.w. m.n. Kortmann; NJCM-Bulletin 1989, p. 581 e.w. m.nt. A.W. Heringa.

Zie voor de reactie van de minister TK 1988-1989, 20469, nr. 30 en welswoorstel tot wijziging van de Harmonisatiewet, "TK. 1988-1989, 21 157, Stb. 1999, 295. 
satiewet in strijd acht met gerechtvalardigde verwachtingen van de betrokken studenten en derhalve met het rechtszekerheidbeginsel.

De Hoge Raad oordeelde eveneens dat artikel 120 Grond wet (Grw) in de weg staat aan toetsing van de formele wet aan ongeschreven fundamentele rechtsbeginselen. Maar de Hoge Raad merkte op dat de rechtsontwikkeling sedert het tot stand komen van de Grondwet van 1983 het gewicht van de voór restrictieve interpretatie van het toetsingsverbod pleitende argumenten heeft doen toenemen.

Ook de Hoge Raad stelt zich dus kritisch op tegen de wetgever. Hij sluit niet uit dat hij misschien in de toekomst de formele wet wel zal gaan toetsen aan die fundamentele rechtsbeginselen. ${ }^{4}$

Ook al is de Haagse president 'teruggefloten', het feit dat hij het heeft aangedurfd cen aantal formele wetsbepalingen buiten toepassing te laten wegens strijd met artikel 43 Statuut is op zich al heel bijzonder. Het getuigt van een fundamenteel andere houding tegenover de wetgever dan een rechter zich nog maar pakweg tien jaar geleden had durven permitteren. Nu zou dit kunnen liggen aan de persoonlijkheidsstructuur van de desbetreflende president, maar de jurisprudentie laat zien dat er meer aan de hand is.

Ook de Hoge Raad zelf weet van wanten. Vanaf 1980 heeft de Hoge Raad op het terrein van het personen- en familierecht een aantal ingrijpende beschikkingen gewezen, dat dit deel van ons recht - dat in 1970 in werking is getreden - radicaal heeft gewijzigd. Ik volsta met het noemen van de beschikking van de Hoge Raad van 4 juni 1982.5, 6 De Hoge Raad achtte de toepassing van het (inmiddels vervallen) artikel 1:36 lid 2 BW

4. De Hoge Raad merlk op dat de rechtspraak is gaan aanvarden dat strikte toepassing van de wet onder omstandigheden zozeer kan indruisen tegen fundamentele rechtsibeginselen dat zij achterwege moet blifven (HR 12 april 1978, NJ 1979, 533 en HR 15 juli 1988 , AB $1988,600 \%$. De HR begeeft zich nat mijn moning hier op een zijspoor. A-G Mok merkt in zijn conclusic (4.2.5 Contra-legem toepassing van algemene rech bbeginselen) terecht op dat verweerders ten onrectste van mening zinn dat de Hoge Raad de wef in formele zin al eerder heeft getoetst aan algenene rechtsbeginselen. Bij de zogemaamde doorbraakarresten was er sprake van beschikkingen die in overeenstemming zujn met de wet, maar in strjid met door het bestur gewekte werwachtingen. Mok wijgt op wee belangrijke verschillen. In de cerste plats is to geon sprake van toetsing wan de wet Het bestur heeft het vertrouwen gewekt dat cen burger gunstiger zou worden behandeld dan wit de wet woortwoent. In de weede plats gat het om vertrouwen dat het bestutur, dat voor de beoondee de beschikking verantwoordelijk is (dat kan in belastingzaken de inspecteur zijn, maat ook de bewindsman), zelf heeft gewelkt. En ä nooit beshist dat ook door de wetgever gewelkt vertnowwen van belang kan zin ch net name thiet dat de butger bij verandering van wetgaving aan de vroegere (voor bem gunstiger) wet in rechte vertrouwen kan ont lenen.

5. NJ 1983,32 m.nt. EAA.

6. Zie verder voor de wijze warop de burgerlijke kamer van dle Hoge Raad met formele wetsbepatingen ongat $0 . \mathrm{m}$. mijn preadvies 'De toepassing var het internationate recht. doon de Nederlandse (administratiewe) rechter in: Staatsrecht, buitenlandse betrekkingen en de internarionale rechtsonds, Staatsechtconferentie 1986, Nijmegen 1987. 
niet verenigbaar met het in artikel 12 Europees Verdrag voor de Rechten van de Mens (EVRM) toegekende recht om te huwen. Op grond van het toenmalige artikel 1:36, lid 2 BW was de vervangende huwelijkstoestemming van de kantonrechter niet geoorloofd indien een ouder, die het gezag over zijn wettig kind uitoefent, zijn toestemming weigerde.

Ook administratieve rechters deinzen er niet (meer) voor terug formele wetsbepalingen buiten toepassing te laten wegens strijd met een ieder verbindende verdragsbepaling. Zo verklaarde de Centrale Raad van Beroep (CRvB) op 5 januari 1988 een aantal bepalingen van de Wet invoering gelijke uitkeringsrechten voor mannen en vrouwen buiten toepassing, ondat de bij deze wet onder meer in de Algemene arbeidsongeschiktheidswet geïntroduceerde inkomenseis in strijd werd geoordeeld met het beginsel van gelijkke behandeling, zoals neergelegd in artikel 26 Internationaal verdrag inzake burgerrechten en politieke rechten (Bupo). ${ }^{?}$

De dynamische en actieve houding van de rechter heden ten dage is niet iets specifieks Nederlands. Het arrest van het Europese Hof voor de Rechten van de Mens van 23 oktober 1985, de zogenaamde Benthem-case ${ }^{8}$, bracht een schok te weeg in juridisch Nederland, hoewel deze uitspraak niet geheel onverwacht kwam. ${ }^{9}$ Een essentieel deel van her Nederlandse bestuursrecht, het zogenaamde Kroonberoep dat in meer dan honderd wetten is geregeld, bleek, althans in een aantal gevallen, in strijd met artikel 6 van het EVRM. Dit arrest heeft geleid tot de Tijdelijke wet Kroongeschillen ( $T w K$ ), die op 1 januari 1988 in werking is getreden. ${ }^{10}$ In deze wet is, voor zover het appellabele besluit een de burger rakende beschikking is, het Kroonberoep vervangen door een beroep op de Afdeling geschillen van bestuur van de Raad van State (AGRvS), die als onafhankelijke administratieve rechter optreedt.

7. CRvB 5januari 1988, AB 1988, 252-254. Zie hierover R. Bakker, De wisselwerking tussen nechter, Raad wan State en wetgever op het ternein wan de Sociale zekerheid, RegelMaat 199, nr. 1 .

8. $A B_{0} 1986,1 \mathrm{~m}$.nt. Hirsh Ballin.

9. G.J. Wiarda wees er reeds in 1979 op dat moet worden angeromen dat de rechtbe. scherming tegenover de overtheid, zoals deze in Nederland is geregeld, in the bjoonder wan burgerlike rechten en verplichtingen de invloed ondergan van administ ratieve beschilkkingen waartegen alleen bij de Kroon kan worden opgekomen, niet aan de cisen van art. Gild 1 EVRM voldoet. (De betekenis van art, 6, lid I van het Europese Verdrag tot bescherming wan de rechten van de mens voor de Mederlandse administ micwe rechesgangen, in: Non sine causa, opstellen aangeboden aan prof. mr. G. I. Scholten, Zwolle $1979, \mathrm{p}$. $459 \mathrm{e}$. w, ook opgenomen in "Verspreide geschriften van G.J. Wiarda, Den Haag 1986, p. 213 e.v.)

ע0. zie bierover J.B.J.M. ten Berge, M.C. Burkens, P.J.J. wan Buuren, De Tijdelijke wet Kroongeschillen, Zwolle 1987. Zie voor de exste jurisprudentic: F A M. Stroink, A.Q.C. Tak, J.M.H. F. Teunissen, Een analyse van éen jaar TwK-jurisprudentie, NJB 1989, p. 253 c.v.; Rosa Uylenburg, De Afdeling wor de geschillen van bestumals recher, NTB 1988, p. 164 a.v en J.G. Stenbeek, De TwK nas! de wet Arob, NTB 1988, p. $197 \mathrm{e.v}$. 
Als contrast met deze recente rechterlijke uitspraken noem ik een arrest van de Hoge Raad van nog geen dertig jaar geleden, thet zogenaamde Geertruidenberg II arrest. " De vraag was of het in (het toenmalige) artikel 184 lid 2 Grondwet vervatte processieverbod veremigbaar was met de in artikel 9 van het EVRM neergelegde belijdenisvrijheid. Op grond van het rweede lid van dat artikel kan de vrijheid van godsdienst of overtuiging te belijden aan geen andere beperkingen zijn onderworpen dan die welke bij de wet zijn voorzien en die in een democratische samenleving nodig zijn in het belang wan de openbare veiligheid, woor de bescherming van de openbare orde, gezondheid of zedelijkheid, of de bescherming van de rechten en vrijheden van anderen. De Hoge Raad oordeelde dat het resultaat van de afweging wan de belijdeniswrijheid tegenover de noodzaak de openbare orde te handhaven voor een rechterlijke toetsing in thet algemeen niet vatbaar is en dat daarom zal moeten worden aangenomen dat de inhoud van de norm waarin een op zichzelf gewettigde beperking van enige in het verdrag gewaarborgde vrijheid is neergelegd, in beginsel aan rechterlijke beoordeling is onttrokken en voor de verantwoording moet blijven van de nationale wetgever. Er is slechts ruimte voor ingrijpen van de rechter "indien het ten enenmale ondenkbaar zou moeten worden geacht dat een wetgever, gesteld voor de noodzaak met het oog op de bescherming van de openbare orde te dien aanzien een regeling te treflen, daartoe een zodanige regeling in redelijkheid zou kunnen treffen of handhaven'.

$\mathrm{Nu}$ is de geconstateerde tegenstelling wellicht niet helemaal zujver, orndat aan de betreffende wetgever - in casu was dat de Grondwetgever - een redelijke mate van beleidsvrijheid toekwam om het belang van een ongestoorde bejijdenisvrijheid af te wegen tegen het. belang van het voorkomen van wanordelijkheden. Maar termen als 'in het algemeen niet voor rechterlijke roetsing vatbaar' en 'ten enenmale ondenkbaar" zullen, naar mijn stellige overtuiging, door de Hoge Raad niet meer worden gebezigd. ${ }^{12}$

11. HR 19 jannari $1962, \mathrm{NJ} 1962,107$.

12. Art. 184 lid 2 Crw 1972 lixerde de toestand op 1848. Het artikellid luidde: Onder dewalfe bepaling blijli de openbare godsdienstoefening buiten de gebouwen en bestoten platsen geoorloold, war zij hans naar de weten en reglementen is toegelaten. Ditartikel was in 1848 ingevoerd en "thans" slaat dus op 1848. Men kan met recht beweren dat in redelikheid de situatie in 1962 niet beoordeeld kan worden naar de matstaf van 1848.20 ook P.G. Langemeijer in zijn conclusit. De HR legde echter exn ander criterium aran. Sinds 1988 word de materie naast een ieder verbindende verdragsbe pallingen behecist door ar\%.6 Grw en de Wel openbare manilestaties van 20 april 1988, Stb. 157 (zie art. III Additionele artikelen (Grw). 
De rechtsbescherming die de rechter tegen de overheid biedt, is na wereldoorlog II in een stroomversnelling geraakt. De Hoge Raad, die op grond van artikel $1401 \mathrm{BW}$-acties reeds aan het begin van deze eeuw bescherming is gaan bieden ${ }^{13}$, heeft met name vanaf eind jaren veertig op dit gebied uitermate belangrijke uitspraken gedaan. ${ }^{14}$ Voor zover het beschikkingen betreft is de taak van de burgerlijke rechter nu voor het overgrote deel overgenomen door administratieve rechters. Dat heeft zijn voordelen ${ }^{15}$, omdat een administratieve rechter dichter bij het bestuur staat en een beschikking intensiever zal toetsen dan de burgerlijke rechter die verder van het bestuur staat en de neiging heeft on discretionaire bevoegdheidsuitoefening marginaler te toetsen. Een doorbraak vond plaats in 1976, toen de Afdeling Rechtspraak van de Raad van State op grond van de Wet $A R O B$ werd belast met algemene aanvullende administratieve rechtspraak. Andere administratieve rechters zijn altijd belast met rechtspraak op een bepaald beperkt terrein. De Afdeling rechispraak en haar voorzitter hebben de algemene beginselen van behoorlijk bestuur met kracht verder ontwikkeld zodat het bestuur nu, voor zover het AROB-appellabele beschikkingen betreft, onder een stringente rechtsmatigheidscontrole staat. Maar het heeft lang geduurd voordat het zover was. ${ }^{16}$ Administratieve rechtspraak, en algemene administratieve rechtspraak in het bijzonder, is lange tijd door een belangrijke groep staatsrechtgeleerden bestreden. ${ }^{17} \mathrm{De}$ gedachtengang was dat een democratisch bestuur voldoende waarborgen bood voor de burger. Daarbij speelde ook een zekere angst voor rechterlijke inmenging in het bestuur en de gedachte dat rechtmatigheid en doelmatigheid moeilijk te scheiden zijn. Deze gedachten hebben lang doorgewerkt. Het artikel 74 lid 1 Wet administratieve rechtspraak bedrijfsorganisatie 1954 getuigt daarwan. Dit artikellid Ituidt:

13. Zie bijvoorbeeld HR 10 mei 1901, W 7606 (Rotterdams woonhuis); het bekende Guldemond-arrest (HR 31 december 1915, W 9947) waarin de Hoge Raad de leer van het objectum litis neerlegde, on HR 20 november 1924, NJ 1925, p. 89 (Ostermann-arrest): ook de niet-nakoming van een publiekrechteljke rechtsplicht levert cen onrech mat ige dad in de zin van art. $1401 \mathrm{BW}$ op.

14. Zie bijwoorbeeld HR 14 januari 1949, NJ 1949, 557 (Zandwoortse woonrumtevordtering); HR 25 lebruari 1949, NJ 1949,558 (Doetinchemse woonnumtevordering) en HR 9 meil 1958, NJ 1960,475 (Rijbewijs-arrest).

15. Overigens niet alleen maar woondelen. Een benadeelde burger moet na een vernietiging door de Adcling rechtspraak woor een volledige schadewergoeding naal de burgerlifke rechter (art. 99 lid 3 Wet RwS).

16. De ontwikkelingen in de worige eeuw - denk bijvoorbeld aan het zogenaamde Conthictenlbesluit 1822.1844 - laat ik buiten behandeling.

17. De grote exponent was A.A.H. Struycken, met zijn bekende brochure Administratie of rechter", Armhem 1910 (een reactipu op de voorstellen Loef), gevolgd door velie anderen waarvan ik met name $G$. van den Bergh noem. 
'Indien een uitspraak naar Ons oordeel in haar gevolgen in strijd komt met het algemeen belang, kunnen wij op woordracht wan Onze betrokken Ministers besluiten dat zij geen of niet volledig gevolg zall hebben."

Dit artikellid getuigt van een angst van de wetgever voor administratiefrechterlijk ingrijpen en geeft aan de Kroon een bevoegdheid die in alle opzichten met de positie van de onafhankelijke rechter in strijd is. ${ }^{18}$ Het siert de Kroon overigens dat zij van deze bevoegdheid nooit gebruik heeft gemaakt. De 'democratische' gedachte heeft ook doorgewerkt in het instituut van het Kroonberoep dat door weel beofenaren van het staats- en bestuursrecht altijd met veel sympathie is behandeld. De procedure geeft de burger veel waarborgen ${ }^{19}$, maar het is uiteindelijk het bestuur dat beslist. Het Kroonberoep in Hinderwetzaken - ik heb de Benthem-case all ter sprake gebrach - bleek echter in strijd met artikel 6 , lid $\mathbb{1}$ van het Europees Verdrag voor de Rechten van de Mens (EVRM) ${ }^{20}$ Indien er sprake is van het vaststellen van zajn burgerlijke rechten en verplichtingen, heeft een burger het recht op toegang tot een onafhankelijke rechter. Welnu, het Europese Hof te Straatsburg oordeelde - en dat was voor velen tach wel verrassend - dat bij het weigeren van een Hinderwetvergunning burgerlijke rechten in het geding zijn. Aangezien de Kroon geen rechterlijke instantie is, kon zij in Hinderwetzaken niet meer un administratief beroep als eind instantie optreden. Het vervangen van het Kroonberoep door een beroep op de Afdeling voor de Geschillen wan Bestuur van de Raad van State heeft tot gevolg dat nu in de meeste gevallen ${ }^{21}$ een belanghebbende burger tegen een beschikking in beroep kan gaan bij een administratieve rechter. Men mag ervan uitgaan dat de geplande integratie van de administratieve rechters in de rechterlijke macht ${ }^{22}$ op den duur zal leiden tot eenvormigheid van her administratief procesrecht, hetgeen samen met de organisatorische integratie tot meer doorzichtigheid en helderheid van het systeem zal leiden.

Op het terrein van de privaatrechtelijk contracterende overheid zijn eveneens belangrijke ontwikkelingen te melden. Langzaam maar zeker wordt ook die privaatrechtelijk optredende overheid door de burgerlijke rechter aan de algemene beginselen van behoorlijk bestuur en de grond-

18. Cf stelling 3 bij de dissertatic van $G$. Flinterman, De act of state doctrine, dissertatie Leiden, Antwerpen/Amsterdarn 1981 .

19. Zie ant. 26 lid 1 Wei $R$ w S en art. $32 \mathrm{ev}$. Wet RvS, met name art. 57 en 58.

20. $Z$ ie noot 8 .

21. De Wet AROB kent een aantal uitgezonderde categorieën beschikkingen (zie art. 1, 5 en $6 \mathrm{Wet} A \mathrm{ROB}$ ).

22. Zie he Eindrappori van de Staatscommissie Herziening Rechterlike Organisatie (deel 1), Den Haag 1984 (commissic van Zcben), en het kabinetssandpunt Naar een nieuwe structuur van de rechienlike organisatie, 1989, TK 1988-1989, 21 206. Zie over de reorganisatie van de rechterligke macht de Staatsrechtconferentie Heerlen 1989, IJmuiden 1990 . 
rechten gebonden. ${ }^{23}$ Voor zover het feitelijke handelingen betreft - indien althans de administratieve rechter niet bewoegd is - hangt het ervan af of deze handelingen zijn te beschouwen als uitwloeisel wan een publieke taak (bijvoorbeeld beheer) of bevoegdheid dan wel of het feitelijke handelingen betreft die een ieder kan verrichten. In het eerste geval zullen eveneens publiekrechtelijke beginselen doorwerken. ${ }^{24}$ In het tweede geval zal de overheid door de burgerlijke rechter op éen lijn met de burger gesteld worden.

Niet alleen op het terrein van het bestuur maar ook op het terrein van het algemeen verbindend voorschrift hebben zich de afgelopen decennia belangrijke ontwikkelingen voorgedaan in het rechterlijk optreden.

Alvorens die ontwikkelingen te schetsen moet opgemerkt worden dat de Nederlandse rechter het reeds lang "van nat ure" tot zijn bevoegdheid heeft gerekend in het hem voorliggende geschil een lager algemeen verbindend voorschrift (avv) te toetsen aan een hoger. De rechtsorde vormt én geheel en het past niet dat binnen die rechtsorde onverenigbare avv-en rechtsgeldig kunnen functioneren. Aan de top van de hiërarchieke ladder van de avv-en staat de een ieder verbindende verdragsbepaling. Een uitzondering op dil. systeem vormt de 'onschendbaarheid' van de wet tegenover de Grondwet (artikel $120 \mathrm{Grw}$ ) en, zo weten we nu, tegenover het Statuut. ${ }^{25}$ Indien een lager avv niet verenigbaar wordt geacht met een hoger avv leidt.

23. Zie art. 3.1.115 nieuw BW; art. 3.1.1 lid 2 voorstel van wet Algemene wet bestuurstecht, TK. 1988-1989, 2ע 221, nr. 2 en HR 27 maart 1987, AB 1987, 273 m.nt. FHwdB (Ikon-alrest). 24. Zie bijwoorbeeld HR 29 maart $1940, \mathrm{NJ} 1940,1128$ (Heldenkermis-arrest); HR 9 januari 1942, NJ 1942, 295 (Wegdek-arrest) en HR 9 okiober 1981, AB 1982, 49 m.nt. Steenbeek (Waterschap Baggenbeek).

25. Prakke, Toetsing in het publiekrecht, Assen 1972 , p. 76, bestrijdt in een reactie op Van der Pot-Donmer dat het (toenmalige) art. 131 lid $2 \mathrm{Grw}$ de enige uitzondering vormt op de bevocgdheid van de rechter lagere regelingen op thun geldigheid te toetsen. Hij noemt art. 193 lid 2 en 220 lid 6 gemeentewet en art. 93 lid 7 Wel op de bedrifsorganisatie. Ari. 1931 Jd 2 germeentewet houdt natar mijn mening geen rechterlijk toetsingswerbod in. De rechter loetst bepalingen uit gemeentelijke verordeningen aan provinciale en rijkgregelingen en bij strijd verklawit hij de lagere bepalingen onverbindend. Of er sprake is van en gemeentelijk belang of een provincial or rijksbelang is niet een vraag waar een rechter zich mee bezig behoort te houden. Voor wat betreft art. 220 lid 6 gemeertewet wrag itk me af of de rechter zich beden ten dage zal laten afsehrikken door de woorden "bij twiffel". Hooggtens zal hij wat marginaler toetsen, maar dat ligt bij noodverordemingen toch al woor de hand. Bij art, 93 lid 7 Wet op de bedrijfsorganisat ie lijk er inderdaad sprake te zijn van een verbod van rechterlijke toetsing voor wat betneft de vraag of er sprake is van cen onderwerp als bedoeld in het eerste lid. De bevoegdheid van de rechter een bepaling uit een dergelijke verordening overigens onwerbindend ie verklaren wegens strujd met een hogere tegeling bliff uiteraard onverlet. 
dat tot (gehele of gedeeltelijke) onverbindendverklaring dan wel tot buiten toepassing laten van het lagere avw. ${ }^{26,27}$

Het Nederlandse systeem van administratieve rechtsbescherming heeft zich voornamelijk ${ }^{28}$ gericht tot beschikkingen. Een rechtstreeks beroepsrecht tegen een avv werd niet in overeenstemming geacht met de procedure van totstandkoming van een avv, namelijk door of in samenwerking met een volksvertegenwoordiging. Dit argument is obsoleet omdat vele avw-en op basis van delegatiebesluiten afkomstig zijn van bestuursorganen. $^{29}$

Tot 1969 werd het voor onmogelijk gehouden dat men het uitwaardigen van een onrechtmatig geacht avv rechtstreeks kon aanvechten bij de burgerlijke rechter op grond van een onrechtmatige daadsactie. In dat jaar echter wees de Hoge Raad het Pocketbook II-arrest. De Hoge Raad oordeelde dat de staat onrechtmatig handelde door een ministeriële verordening wit te vaardigen die in strijd was met artikel 7 Grondwet. ${ }^{30}$

In 1986 wees de Hoge Raad het zogenaamde Landbouwvliegers-arrest. ${ }^{3.1}$ In dit arrest werd een ministeriële verordening getoetst aan het willekeurbeginsel. Hiermee is de weg geopend naar het toetsen van avv-en, die geen formele wetten zijn, aan ongeschreven rechtsbeginselen.

Zoals al uit de inleiding is gebleken is er eveneens sprake van een

26. Art. 94 Guw spreekt expliciet over buiten toepassing laten. De lacto zal buiten toepassing laten in de regel overeenkomen met gehele of gedcelted jike onverbindendverklaring. Wan. neer immers in een concreet geval buiten toepassing word ge laten, zal dat in overeenkomstige gevallen ook gebeuren. Zie daarover mijn preadwies genoemd in noot 6. Zie voor een (herziene) theorie om een verschil tussen onverbindendverklaring en buiten toepassing te const tueren R.E. de Winter, Toetsing van gemeentelijke verordeningen door de strafkamer van de Hoge Raad, paragraar 5: De gevolgen wan toetsing, VAR XGVI 1987 p. 236 e.v. 27. Het CBB en de CR VB plegen bij dere toetsing an ongeschreven rechtsbeginselen te toetsen; de Addeling rechispraak niet.

28. Soms ook tot handelingen. Zie art. 4 lid 2 Wet $A R B O$ en art. 3 Ambtenarenwet. Zie cehter ook art. 60 lid 6 Ambtenarenwet: "Woor zover een handeling strekt ter uitvoering van een beshluit, is het begen de handeling gerichte beroep niet-ontwankelijk, indien niet tijdig tegen he beshit theroep is ingesteld.' In de jurisprudentie van her CBB wordt meestal aangenomen dat er sprake is wan een beroep tegen het bestuit om te thandelen. Zie verder over de werschillende bewoegdheden van administratieve vechters mijn brochure "Admini. strutieve rechispratk en rechterlijke macht.', Zwolle 1985.

29. Zic woor cen krachig pleidooi voor een rech streeks beroepsrecht bij de administratiewe rechter indake awven R. M. van Male, Rechter en bestuurswetgeving; Zwolle 1988. Zie voon argumenten om er niet hals over kop toe over te gaan F.A.M. Stroink in: "Tien jaar Wet AROB: Hoe verden?", geschriften VAR XCVII, Alphen aan den Rijn 1987, p. 33 c.

30. HR 24 januari 1969, NJ 1969, $316 \mathrm{mmt}$. H. Drion.

31. HR 16 mei 1986, AB 1986, 574 mint. PvB. Zie over de toetsing van wetgeving de preadviezen van P.J.J. wan Buten en J. E.M. Polak voor de NJV, Zwolle 1987: 'De rechter en onrechimatige wetgewing". 
rechterlijke voortvarendheid - een term van Wiarda ${ }^{92}$ - ten opzichte van de formele wet. Tot eind jaren zeventig/begin tachtig werd de formele wet zo geïnterpreteerd dat er geen sprake was van strijd met een ieder verbindende verdragsbepaling. Vanaf die tijd is de houding van de rechter grondig gewijzigd. Indien de nationale rechter een formele wetsbepaling in strijd acht met een ieder verbindende verdragsbepaling wordt deze nationale bepaling in de regel buiten toepassing gelaten. ${ }^{33}$ Overigens is buiten toepassing llaten niet altijd nodig om het door de rechter gewenste effect te bereiken. Soms kan de rechter zijn doel bereiken met een - wel eens gewaagde - verdragsconforme interpretatie. ${ }^{34}$ Ik kan instemmen met deze jurisprudentie. Ik zie niet in waarom de rechter terughoudender zou moeten toetsen indien een formele wetsbepaling in het geding is. De terughoudende toetsing tot pakweg 1980 is wellicht historisch verklaarbaar: een grote eerbied voor de formele wet, de uitdrukking van de volkswil, die niet getoetst mag worden aan de Grondwet.

Overigens kan de rechter niet altijd een oplossing bieden. Met een onverbindend-verklaring/buiten-toepassing-laten bereik je met name iets als je de overheid wil tegenhouden. Indien een bepaalde prestatie van de overheid verlangd wordt, biedt de rechter niet altijd soelaas. Indien er bepaalde keuzemogelijkheden zijn heeft de Hoge Raad in een aantal gevallen het standpunt ingenomen dat het niet binnen de rechtsvormende taak van de rechter valt zelf die keuze te maken. ${ }^{35}$

32. G.J. Wiarda, Rechterlijke voortvarendheid en rechterlijke terughouding bij de toepassing van de Europese Conventie tot bescherming van de rechen wan de mens Den Haag 1986.

33. Zie HR 4 juni 1982, NJ 1983,32 m.nt. EAA waarin het inmiddels ingetrokken artikellid van art. $1: 36$ lid 2 BW buiten toepassing werd gelaien.

34. Zie bijwoorbeeld HR 4 mei 1984, NJ 1985, 510 m.nt. EAAL en EAA betreffende de interpretatie van art. 1:161 lid 1 BW.

35. Zie bujvoorbeeld HR 12 oktober 1984, NJ 1985, 230, AA 1985, p. 209 e.v. m. nt. Jessurun d"Oliveira. Het ging hier om strijd van art. 8 Wet op het Nederlanderschap (immiddels vervangen) mell art. 26 Bupo. De Hoge Raad overwoog: "... De vraag in welke gevallen het bij of

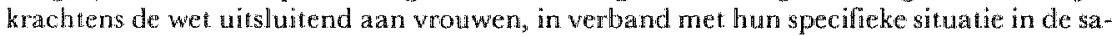
menleving, toekennen van een bepaald recht, naar strekking van art. 26 wan het Verdrag van New York in sirjid moet worden geacht met het aldaar neergelegde beginsel kan hier in het midden worden gelaten. Aan ari. 94 van de Grond wet in verband met art. 26 van het Verdrag kan immers geen grond worden ontleend om, ter voorkoming van een versethillende bew handeling van mannen en vrouwen, aan mannen ee nzelfde recht toe the kemen als de wet slechts aan vrouwen toekent, in het geval dat bet in de wet neergelegde versehil in behandeling, gezien de aland van het recht, in redelijkheid ook op andere wijze kan worden weggenomen en op dit punt een keuze moet worden gemakt, die, mede in aanmerking genomen de aard van de daarbij betrokken belangen, niet bimnen de rechisvormende taak van de rechter vali. In dat - zich hier voordoende geval w is het aan de wetgever, te bepalen op welke wijze het best aan het beginsel van art. 26 van het Verdrag kan worden voldaan. "Zie hierover A.W. Heringa, Sociale grondrechten, dissertatie Leiden 1989, Den Haag $1989, \mathrm{p}$. 202 e.v. Zie ook HR 23 september 1988, NJ 1989, 740. Het betrof hier het door art. 26 Vendrag van New York gegarandeerde recht van biologische ouders op een door then - 
De Centralle Raad van Beroep (CRvB) daarentegen is eerder geneigd die keus zelf te maken. ${ }^{36}$

Met de zogenoemde voorjaarsbeschikkingen van $1986^{37}$ waar de Hoge Raad wel zelf de keuze maakte ${ }^{38}$, is de Hoge Raad ver gegaan. In deze beschikkingen werden richtljinen gegeven die een sluitend systeem geven inzake de mogelijkheid onder bepaalde voorwaarden van ouderlijke macht van gescheiden en nooit gehuwd geweest zijnde ouders. Met deze beschikkingen is naar mijn mening wel de grens bereikt waartoe de rechter kan komen; wellicht is dic grens zelfs overschreden. ${ }^{39}$

Met de voorjaarsbeschikkingen is de Hoge Raad inderdaad op de stoel van de wetgever gaan zitten en is hij opgetreden als wetgever-plaatsvervanger. ${ }^{40}$ De rechter raakt ook gauw aan het wetgever-plaatsvervangerschap als de formele wetgewer het laat afweten. De positie van de rechter dreigt in gevaar te komen indien de formele wetgever de oplossing van politiek zwaar liggende problemen op het bordje van de rechter legt. De

- te kiezen geslachtsnaam woor hun kinderen. Ook thier zag de Hoge Raad gezien de vele keuzemogelijklieden geen taak woor zichzell maar woor de wetgever.

36. CRvE 7 december 1989, AB 1989, $10 \mathrm{~mm}$ nt.. JHS. De CRvB overwoog: 'De Raad is wan oordect dat her voor Nederland geldende, ook reeds in de 'oude" Grondwet neergelegde stelsel wan het doorwerken van international en supranationaal recht met zich mecbrengt dat bij de rechterlijke beslissing de discriminatie in het geval er strijd met art. 26 IVBP bustat on aan dit artikel rechtstreekse werking tockom, moet worden opgehewen, ook wanneer de discriminatie niet aan cen uitzonderingsbepaling is toe te schriven. Dat stelsel laat derhalve, wat de. AWW betreft, nanir het oordeel van de Raad niet toe dat hij zou volstaan met het noemen wan de wetgever als hebbende exchsief de teak om - zoals in wezen namens de eiser is bepleit - bij strijd van de AWW amet art. 26 IVBP, welke is ontstaan als gevolg wan nictuijdige opheffing wan discriminatie door wetswijziging, een oplossing te zoeken voor de tijd dat die strijdigheid reeds bestaat en nog zal voortduren. De rechtstrekse werking dient voor hef ter toetsing van de rechter staande geval het effect te hebben dat bij het bestaan van recht op uitkering en pensioen van weduwen op grond vande AWW aan de na het overlijden van een der echtelieden atchterblijuende de in deze wet voor en weduwe woorziche aanspraken tokomen, ongeacht of de achterblijvende de man dan wel de wroum is."

37. HR 21 mant 1986, RvdW 1986, 162-165; NJ 1986, 585-588 m. nt. EAA en EAAL. Zate oved deze beschikkingen M. Rood-de Boer, Duidelijkheid en zekerkeid, MJB 1986, p. 601 e.w. en A.W.M. Willems, NJB 1986, p. 604 e.v.

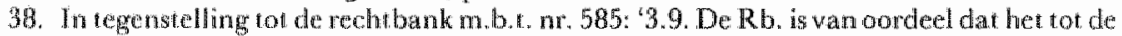
takk van de wetgewer behoort en niet tot de taak van de rechter om vast te stellen in welke fevallen en onder wetke voonwarden de juridische relatie tussen ongehuwde ouders on hun kinderen op dezelfde wijut moet worden geregeld als de relatie tussen gehuwden en hun kinderen."

39. Alkema merkt in nool 1 bij nr. 588 op: 'Zij reiken verder dan het concrete geval, zetten geldende wetgeving butten spel (...), formuleren in bet algemeen de voorwararden woor de verlening van de ouderlijke macht en wijen cle bevoegde rechter aan (. . ). Dat is meer wetgeving dan rechtsprak." Luyten bestrjjd in noot $2 \mathrm{~m}$. 588 dat de beschikkingen wel aanshuiten bij de maatschappelijke onrwikkelinger.

40. De rem is oorspronketijk athomstig wan M.J.P. Verburgh, NJB 1977, p. 508 . 
rechter weet dit probleem overigens vaak te omzeilen door te kiezen voor procedurele oplossingen. ${ }^{\text {*1. }}$

Overigens ben ik niet zo gelukkig met de term wetgever-plaatsvervanger. In de gevallen waarin de wetgever het liet (laat) afweten ${ }^{42}$ betreft het weliswaar zeer belangrijke maatschappelijke problemen, maar gelet op het totale owerheidsoptreden betreft het kwantitatief weinig zaken. Voorts is de term misleidend omdat de rechter altijd geadieerd moet worden en slechts uitspraak doet in én casus, al heeft die uitspraak dan ook zekere doorwerking.

De rechter is ook niet geschikt voor wetgeving. Hij is er om concrete geschillen op te lossen.

Als toetsing van een lager avv aan een hoger avv leidt tot onverbindendverklaring staat voorop dat het zo niet kan, maar hoe het wel verder moet staat - althans in de regel - weer ter discretie van de wetgever. Met andere woorden, de primaire functie van onverbindend verklaren is negatilef, namelijk iets tegenhouden. De rechter treedt op als grenswachter. Hij wakt of de wetgevers blijven bimnen de rechtsstatelijke randvoorwaarden, en treedt dus niet zelf op als wetgever.

Zoals al is opgemerkt kan de positie van de rechter in gevaar komen als hij zich teveel in politiek vaarwater moet begeven. In zijn onafhankelijkheid ligt juist de kracht van de rechter. De onalhankelijkheid brengt mee dat de rechter zijn subjectieve opvattingen zoveel mogelijk moet uitsluiten helemaal lukt dat natuurlijk nooit. De rechter moet objectiveren, dat wil zeggen aansluiting zoeken bij wat in de maatschappij leeft en de daar heersende overtuigingen. Indien binnen de maatschappij consensus ont. breekt en zeker indien er sprake is van emstige tegenstellingen, dient de wetgever de oplossing aan te geven. De rechter beschikt dan over onvoldoende aanknopingspunten. Het is dan ook heel begrijpelijk dat bij een nalaten van de wetgever in dit soort situaties de rechter de oplossing zo mogelijk in procedures zoekt. De rechter mag in leder geval ook in dit soort gewallen geen recht weigeren (artikel 13 Wet $A B$ ). Hier ligt een zwar spanningsveld tussen wetgrever en rechter.

Het lijkt erop dat de meer activistische houding van de rechter in de jaren tachtig gepaard gaat met een gewijzigde houding van de burger tegenover de rechter. Werd in de jaren zestig en zeventig veelal wantrouwen uitgesproken tegen de rechter wiens positie niet is gebaseerd op democratische legitimatie en die veelal alkomstig is uit de maatschappelijke bovenlaag ${ }^{43}$,

41. Zie G.I. Wiarda, Drie typen van rechtsvincing, Zwolle 1988, derde druk, p. 103.

42. Men denke aan gevolige onderwerpen als staking, abortus en euthanasie.

43. A. . Cnoop Koopmans, Recher en politick, NJB 1973, p. 630 e.\%, A.J. Hoekerma, Vertrouwen in cle justitie, Alphen aan den Rijn 1971. 
in de jaren tachtig hoort men meer geluiden die juist vertrouwen in de rechter uitspreken. "Nu is er eerder een gebrek aan vertrouwen in wetgever en bestuur.

Hoe moet men aankijken tegen de gewijzigde, meer activistische houding van de rechter van de laatste jaren?

Ik ben geneigd deze houding in principe toe te juichen. In principe, want de rechter moet wel zijn grenzen weten. Overschrijding van de grenzen van de rechterlijke functie kan tot een diepe val leiden.

Een meer voortvarende houding van de rechter is van belang vanuit een oogpunt van revitalisering van de machtenscheiding, van het systeem van 'checks and balances". ${ }^{5}$ In een moderne westerse staat past een sterke rechter als tegenwicht tegen de sterke machtsconcentratie van wetgeverregering en de bureaucratie. Er is niet zozeer meer sprake van 'trias' maar van een "duas". "Een activistische houding van de rechter is nodig om het evenwicht tussen democratic en rechtsstaat te herstellen.

Uit het voorgaande blijkt dat het gehele overheidsoptreden - op ëen belangrijke uitzondering na: de toetsing van de formele wet aan de Grondwet (en het Statuut) - aan rechterlijke controle is onderworpen.

Zowel de gewone rechter (de burgerlijke rechter en de strafrechter) als de administratieve rechters spelen een belangrijke rol inzake de toetsing van lagere avv-en aan hogere awv-en. De administratieve rechters vervullen een belangrijke taak bij het toetsen van met name beschikkingen aan geschreven en ongeschreven recht. De burgerlijke rechter springt in als zogenaamde restrechter ${ }^{47}$ als er inzake beschikkingen geen met voldoende

44. M.G. Rood, Rechtszekerheid voor bet bestuur? in: Het bestuur uitgedaagd door het recht, Den Haag 1989, met name p. 54/55.

45. K.M. Schönfeld, Montesquieu et la bouche de la lö́, Leiden 1979, p. 73. Het is hier niet de plaars het oorspronkelijke gredachtengoed van Montesquieu te analyseren. Dat is overigens veel te weinig gebeurd. Schönfeld haalt. Burke aan die gezeggd heeft: 'You say, my dear Sir, they read Montesquieu - I believe not. If they do, they do not understand him". Ik denk dat deze opmerking ook heden ten dage voor Nederland nog opgaat. De grondgedachte van Montesquieu is echter springlevend. Zie over het slecht lezen van Montesquieu ook Ch.J. Enschedle, Montesquieu en de lluoridering, in: 'Beginselen (G. E. Mulder-bundell, Arrathern 1981, p. 43 e.v.

46. Intrerwentie E.J. Dommering vergadering NJV 1987 , Handelingen 1987, p. 17: "In wezen gaat the dus om twee machteri: een politieke en een juridische. Democratie tegenower rechtsstaat ...'; N.S.J. Koeman, Over beleid en controle: Op zoek naar enen opvolger voor de triasteer, NTB 1989 , p. 73 e.v. Zie ook M.R. Wijnholt, Rechterlijke machtsuitoefening, in: "De recher als dictator", RAlO-congresbundel, Lochem 1987. Zie over het relatiewer worden wan het onderscheid beschikking-avv F.A.M. Stroink, J.G. Steenbeek, Inleiding in het stisals-en administratief recht, Alphen aan den Rijn 1985, tweede druk, p. 92 en 93 . 47. Zie ower die restfunctie van de burgerlijke rechter M. C. Burkens, Hoofdstuk 3 Algemeen Commentaar, De plaats van de administratieve rechtspraak in thet consitutionele bestel en de verhouding tot de rechtspraak van de gewone rechter, in: Administratieve rechtspraak overheidsbeschikkingen, Alphen aan den Rijn, losbladig, onder redactie wan J.B.J. sen Berge, B. W.N. de Waard en R.J.G.M. Widdershoven ( $\mathrm{B} / \mathrm{S}$ bundel). 
waarborgen omklede administratieve rechtsgang is. Tevers is het feitelijk optreden aan zijn controle onderworpen indien er geen terzake bevoegde administratieve rechter is, alsmede de privaatrechtelijk optredende overheid. Stormachtig is de ontwikkeling van de rechtstreekse toepassing van avv-en door de burgerlijke rechter op grond van artikel $1401 \mathrm{BW}$-acties.

De vraag die vanzelf rijst is waarom de formele wet in zijn verhouding tot Grond wet een verboden terrein is voor de rechter. Op de beantwoording van die vraag zal ik mijn betoog verder toespitsen. ${ }^{48}$ Deze vraag is uiteraard al eerder gesteld en op verschillende wijzen beantwoord ${ }^{49}$, maar ik meen dat de geschetste recente ontwikkelingen het rechtvaardigen deze vraag opnieuw te stellen.

\section{DE ONSCHENDBAARHEID VAN DE FORMELE WET}

In 1848 werd in de Grondwet de bepaling 'De wetten zijn onschendbaar' opgenomen (art. 115 lid 2 Grw 1848). Overigens had vóór 1848 de verhouding formele wet-Grondwet nooit problemen opgeleverd. ${ }^{50}$ Buys achtte het grote voordeel van deze bepaling dat daarmee de rechtszekerheid werd gediend. ${ }^{51}$ Een a rgument dat heden ten dage overigens nauwelijks opgaat. De burger heeft zeer veel te maken met algemeen verbindende voorschriften die geen formele wet zijn en blootstaan aan de mogelijkheid van rechterlijke onverbindendverklaring. Bovendien kunnen formele wetsbepalingen zelf buiten toepassing worden gelaten wegens strijd met rechtstreeks werkende verdragsbepalingen.

In de Westeuropese negentiende-eeuwse gedachtenwereld paste de onschend baarheid der wet - om deze in 1983 afgeschafte grond wettelijke

48. De verhouding formele wet-Statuut laat ik rusten. Het ligt uiteraard wel voor de hand dat indien toetsing van de formele wet aan de Grondwet mogelijk wordt gemaakt, ook toetsing van de formele wet aan het Statuut wordt gerealiseerd.

49. Zie vanuit de wetenschappelijke hoek met name H.J.M. Jeukens, De werten zijn onschendbar, oratie Tilburg Alphen an den Rijn 1970 nog erg voorachig positief) en van dezelde hand (maar nu stelliger) thet preadvies wan de VAR 1972, LXIX, en L. Prakke, Toetsing in het publickrech, Assen 1972, p. 141 e.v. die in de hoek wan de tegerstanders zit. Het Harmonisatiewetarest heef de belangstelling woor consitutionele toessing sterk doen toenemen. In september 1989 verschech een themanummer van Namens over toesing van wetgeving met bijdragen van J. W.M. Engels, A.H.M. Dölle, E.J. Dommering, E.M.H. Hirsch Ballin en M.L.P. van Houten, P.W.C. Akkermans en E.A. Alkena, In september 1989 verscheen eveneens A.H.M. Dölle en J.W.M. Eragels, Consitutionele rechtspraak, Groningen 1989. Zue voorts P.B. Chteur, Argumenten voor en tegen constitutionele toetsing; NJB 1989 , p. 1369 e.v.

50. Zie Handboek van het Nederlandse Staatsrecht, $C$. W. van der Pot A.M. Donner, Zwolle 1983, elfde druk, p. 175; twaalfde druk, bewerkt door L. Prakke, J. L. die Reede en G.J.M. van Wissen, Zwollie 1989, 19. 193.

51. J.T. Buys, De Grondwet, Eerste Deel, Arnhem 1883, p. 637-638. 
term nog maar te gebruiken - goed. Deze gedachuengang vloeit woort uit de radical-democratische traditie van de Franse revolutie.

De wet is de uitdrukking van de volkssoevereiniteit. Böhtlingk wijst overigens well op een tegenstrijdigheid van het rechtsstaabegrip van de Franse revolutie. ${ }^{52}$ De radicaal-democratische gedachte wijst aan de wetgever een onbeperkte bevoegdheid toe. De wet moet gehoorzaamd worden ondat zij de werkelijke wil wan allen is en ondat deze will niet kan dwalen. De wet is de waarheid. Daartegenover staat de liberale gedachte. De staat had niets anders te doen dan de door de revolutie geschapen samenleving. van wrije mensen te behoeden. Dat impliceerde geen uitbreiding van de staatstaak, aldus Böhtlingk.

Bovendien werd in de theorie - zoals wij al hebben gezien - voor de rechter, en ook voor het bestuur, een zeer bescheiden rol weggelegd. De wet was immers compleet en volledig. Zij diende alleen mar toegepast te worden. Interpreteren mocht de rechter niet. De Franse rechter moest in de eerste jaren na de revolutie - het oordeel van het wetgevend lichaam vragen. $^{53}$

Ook in Nederland heeft deze democratische stroming - om het zo maar even voor het gemak te noemen - grote invloed gehad. De discussie richtte zich echter niet op de positie van de formele wet maar vanaf het einde van de worige eeuw - het is al ter sprake gekomen - op het vraagstuk van de administratieve rechtsbescherming. De clemocratische stroming manifesteerde zich als tegenstander van administratieve rechtspraak. De gedachte was kort weergegeven dat de belangen van de burger in goede handen waren bij het democratisch gekozen bestuur. Men vergat daarbij dat ook democratisch gekozen of gecontroleerde besturen fouten konden maken en dat de belangen van de individuele burger wel eens ten onrechte in de knel konden komen bij de afweging met de algemene belangen.

Langzaam maar zeker echter veroverde de administratieve rechtspraak terrein. Tengevolge van het reeds vermelde Benthem-arrest heeft het administratief beroep als eindinstantie definitief het onderspit gedolven, althans voor zover het beschikkingen betreft.

Bij de Grond wetsherziening van 1953 werd toe tsing van de toepassing van de formele wet aan een ieder verbindende verdragsbepalingen grond wette-

52. F.R. Bohtlingk/J.H.A. Logemann, Het we tsbegrip in Nederland, Aphen aan den Rijn 1966, p. 13-14.

53. D.J. Veegens, Cassatie in burgerligke zaken, weede druk, Zwolle 1971, p. 8 en 9. Veegens behandelt het zogenaamele refécé lacultatil en thet reféré obligatoire (derde drutk. 1989 , bewerki door E. Korthals Alles en H.A. Groen). 
lijk mogelijk genaakt ${ }^{54}$ (art. 65 Grw 1953; nu art. 94 Grw 1983). Daarbij moet wel opgemerkt worden dat men er toen wan uitging dat Nederland in alle opzichten voldeed aan het EVRM. Het is een wat schizofrene situatie dat formele wetsbepalingen niet aan de Grond wet, maar wel aan een jeder verbindende verd ragsbepalingen getoetst mogen worden. Er werden voorstellen ontwikkeld om de mogelijkheid te openen dat formele wetsbepalingen zouden kunnen worden getoetst aan die Grondwetsbepalingen, die de zogenaamde klassieke grondrechten inhouden. ${ }^{55}$ Deze voorstellen hebben het echter niet gehaald. In de Grondwet 1983 is het toetsingsverbod gehandhaafd (art. $120 \mathrm{Grw}$ ).

De gedachte van de onschend baarheid van de wet is historisch vast geworteld. De wetgever, waarvan de rechtstreeks gekozen volksvertegenwoordiging deel uitmaakt, behoort het laatste woord te hebben. De rechter wordt benoemd en heeft derhalve geen enkele democratische legitimatie. De legitimatie van de rechter is in belangrijke mate afhankelijk van zijn onderworpenheid aan de wet.

Men mag van de wetgever verwachten dat hij niet met boos opzet de Grondwet zal schenden. Het gaat primair om de uitleg, de interpretatic van bepalingen van de Grondwet, waar redelijk denkende mensen verschillend over kumnen oordelen.

Vooral waar het gaat om politiek gevoelige zaken ligt het voor de hand aan de wetgever het laatste woord te geven.

Voorts bevat de formele wetsprocedure althans in theorie de nodige waarborgen tegen Grondwetsschending.

\section{DE FORMELE WETSPROCEDURE}

De formele wetsprocedure, zoals deze is neergelegd in de Grondwet en verder is uitgewerkt in de verschillende reglementen van orde, bevat - het is al gezegd - vele waarborgen:

- bij de voorbereiding van wetgeving worden veelal deskundigen en belanghebbenden betrokken. Nederland kent een groot aantal adviescolleges waarin belanghebbenden en deskundigen zitting hebben;

54. Volgens Kortmann (zie noot 3) sloeg ant. 131 lid 2 Grw oud uitslutend op en verbod van toetsing a an de Grw. De bepaling betrof niet the relatie tot werdragen of het vollkendecht in het algemeen. Art. 66 Grondwet oud (nu artikel 94 ) is niet te zien als een wivondering op het toetsingswerbod wan art. 120 Grw. Veeleer legt art. $94 \mathrm{Grw}$ expliciet een toetsingsplicht vast die vớr 1953 niet vasıstond, aldus Kortmann.

55. Zie atc. 78 lid 2 wan de Proeve van ecn nieuwe Grondwel, Den Haag 1967, opgesteld door een commissie bestaande uit Donner, Van der Hoeven, Jeukens, Oud en Rypperda Wierdsma, en art. 14 van het rapport van de staanscommissie Cals-Donner, "Tweede rapport van de staatscommissie wan advies inzake de Grondwet en de Kieswer, Den Haag 1969. 
- de Raad van State adviscert;

- er vindt een openbare behandeling plaats in de direct gekozen Tweede Kamer;

- er vindt eveneens cen openbare behandeling plaats in de undirect gekozen Eersite Kamer.

De wetgevingsprocedure werkt niet altijd zoals deze zou moeten werken. De ratio van een openbare behandeling is dat op grond van een open discussie alle argumenten naar voren kunnen komen. Dat betekent dat de parlementaire meerderheid op grond van die discussie tot een ander standpunt moet kunnen komen dan de regering. Hier zit echter met name het knelpunt. Regeerakkoorden en de wens de coalitie in stand te houden belemmeren cen onbevooroordeelde houding van de regeringsfracties. Goede beslluitvorming wordt voorts belemmerd omdat veelal onder de druk van noodzakelijke bezuinigingen snel besloten moet worden.

Adwisering, met name door een zo gewichtig orgaan als de Raad van State, impliceert dat slechts op deugdelijke gronden van de adviezen wordt afgeweken. Ook daar mankeert het nog wel eens aan. ${ }^{56}$

De Harmonisatiewet collegegelden ${ }^{57}$ is een mooi voorbeeld van wat er mis kan gaan in de procedure die leidt tot een wet in formele zin. De Haagse president - zie de inleiding - verbood toepassing van onder meer art. 35 vierde lid van de Wet op het wetenschappelijk onderwijs (WWO) ${ }^{58}$ juncto art. 9 lid 5 Wet op de studiefinanciering. Opvallend is nu dat dit artikellid niet aan de orde komt in het advies van de Raad van State, niet specifiek de aandacht heeft gekregen in het parlement, maar alleen in samenhang met het - hierna te bespreken - art. 35, lid 5 WWO, en dus ook niet heeft geleid tot amendering door de kamer. De aandacht van de kamer was met name gericht op een ander artikel dat met terugwerkende kracht een einde beoogde te maken aan de mogelijkheid tot verlenging van de inschrijvingsduur wegens persoonlijke omstandigheden, overmacht of omzwaai van studie (art. XIV).

De Harmonisatiewet ziet het hoger onderwijs als één systeem, met als subsystemen het wetenschappelijk onderwijs en het hoger beroepsonderwijs. Was het vóór de inwerkingtreding van de wet zo dar voor beide sub-

56. Zeker in de ogen van staatstaad W. Polak; zie VN, 15 april 1999 , p. 5: ". . Bij sommige departementen krijg ik wel eens het gevoel dit ze de jongste ambtenaar opdracht hebber gegeven on alles wat wij gezegd hebber weg te schrijwen.' Zie woots R. Bakker, Toetsingcriteria van de Ravel van State, paper Staasrechtcongres 1984 Maastricht. In het gros wan de gevallen wordt kritiek van de Raad wan State ter zake van de grondwettigheid wan wetsvoorstellen door de regering weggewoven.

57. TK $1987-1988,20469$, Wijziging van onder meer de WWO, WHBO, WOU en WSF (hamonisatie collegegelden $\mathrm{HO}$, invoering en inschrijungsduun eerste lase $\mathrm{HO}$ ).

58. De corresponderende artikelen 38 lid 3 Wet op het hoger beroepsondersugs en 18 lid 4 Wet op de Open Unwersileit laat ik buiten beschouwing. 
systemen apart een inschrijvingsduur gold van zes jaar, na de inwerkingtreding van de wet geldt de termijn wan zes jaar inschrijving voor het systeem als geheel, met andere woorden als men overstapt van het ene subsysteem naar het andere dan tellen de reeds verbruikte jaren in dat ene subsysteem mee. Na verloop van zes jaar kan men de studie wel vervolgen maar dan in principe op eigen kosten; de studiefinanciering loopt af en het collegegeld wordt hoger. Wel kunnen de instellingsbesturen voor de schrijnende gevallen een tegemoetkoming verlenen uit het zogenaamde auditorenfonds (art. 38 Harmonisatiewet).

Het spreekt vanzelf dat de wijze van berekening van de totale inschrijvingsduur voor van het ene naar het andere subsysteem overgestapte studenten van groot bellang is.

De in casu relevante artikelen in het voorstel van wet zijn:

- art. 35 lid 4 WWO: dit artikkellid - het is al aan de orde gekomen bepaalt onder $a$ dat voor de inwerkingtreding van de wet reeds genoten studiejaren in het $\mathrm{HBO}^{59}$ afgetrokken worden van de zes jaar inschrijvingsduur;

- art. 35 lid 5 WWO: dit artikellid geeft een uitzonderingsbepaling op het vierde lid in dier voege dat voor een student die met goed gevolg een afsluitend examen in het HBO heeft afgelegd en voor de eerste mal wenst te worden ingeschreven als student voor een studierichting aan een universiteit, zo nodig de inschrijuingsduur wordt aangevuld tot twee jaar (voor een deeltijdstudent tot drie jaar);

- art. XIY: dit overgangsartikel geeft in het eerste lid weer een verbijzondering van het vijfde lid van art. 35 WWO. Studenten die voor de eerste maal als student in 1987-1988 in het andere subsysteem zijn ingeschreven, krijgen een maximale aanvulling van de inschrijvingsduur van drie jaar (deeltijders vijf jaar);

- art. XIV: dit artikel heeft voor de meeste commotie gezorgd tijdens de parlementaire behandeling. De tekst van lid 1 luidt: 'Verlengingen van de inschrijvingsduur op grond van artikel 35 vijfde tot en met zevende

59. Alsmede de in modulen nitgedrukte duur van de inchrijving als student an de Open Universiteit. (lid 4 onder b) en de duur van deelneming atan geheel of gedeeltalijk uit de openbare kas bekositigd onderwijs dat door de minister voor de toepassing van dit artikel word gelijkgesteld met onderwijs als bedoeld onder a (het HBO) en $\mathrm{b}$.

60. Lid 2 luid. Twdien betrokkene vooralgand an het sudiejaar $1987-1988$ als studeri voor de in het eerste lid bedoelde studierichting is ingeschreven geweest, wordt het ankal jaren van de eerdere inschrijuingen in mindering gebrach op het in het eerste lid genoends aantal.

Lid 3. luid: 'Dit artikel is uitsluitend van toepassing op degene die met ingang van het studiejaar $1988-1989$ ononderbroke als student aan een wnowersiteit onderseheidendijk aan een instelling voor hoger beroepsonderwijs is ingeschreven."

Lid 4 luidn: "Arthel 9, vijlde lid, Wef op de studiefinanciering is niet. van toepassing op degene die op grond van dit artikel beschikt over inschrijuingsdunt." 
lid, van de Wet op het Wetenschappelijk onderwijs en artikel 38 derde tot en met vijfde lid, van de Wet op het hoger beroepsonderwijs, zoals deze artikelen luidden op de dag voorafgaand aan die van de inwerkingtreding wan deze wet, behouden in afwijking van artikel 35 van de Wet op het wetenschappelijk onderwijs en artikel 38 van de Wet op het hoger beroepsonderwijs hun geldigheid, voor zover een desbetreffend verzoek is ingediend voor 15 september 1987.61

Zoals al is opgemerkt viel de nadruk in de discussie op artikel XIV. De problematiek van art. 35 lid 4 en 5 en art. XII werd niet zozeer toegrespitst op die artikelen maar kwam in wat meer algemene, abstracte betogen aan de orde.

De kritiek van de Tweede Kamer was in alle stadia van de schriftelijke voorbereiding ernstig en zo goed als unaniem. Met het oog op de noodzaak van financiële bezuinigingen hield de regering haar poot stijf. Pas tijdens de plenaire behandeling in de Tweede Kamer kwam de regering met een - derde - nota van wijzigingen ${ }^{62}$, waarin tegemoet werd gekomen aan een aantal verlangens van de $T$ weede Kamer en werd geanticipeerd op een aantal amendementen.

Het is interessant dit beslütvormingsproces wat nader te analyseren.

De Raad van Stat. ${ }^{63}$ merkt op dat hij met de Onderwijsraad van mening is 'dat artikel XIV niet kan worden gehandhaafd. Het artikel doet afbreuk aan de door vigerende wetgeving gewekte verwachtingen bij hen, die voór de datum van inwerkingtreding met hun studie zijn aangevangen. Het betreft hier verwachtingen met betrekking tot het als student kunnen afronden wan een reeds begonnen studie. Het mogelijke nadeel van een groter beslag op de algemene middelen dient, zo meent het college, te worden aanvaard."

De regering handhaaft artikel XIV. Het belangrijkste argument is dat aan de datum van 15 september 1987 niet valt te ontkomen, omdat het financiële beleid woor 1988 nu eenmaal bij de indiening van de ontwerpRijksbegroring wordt bekend gemaakt en niet op een later tijdstip. ${ }^{64}$

Voorts wijst de regering op aanwijzing nr. 75 van de Aanwijzingen voor de wetgevingstechniek. Daarin wordt aangegeven dat een reden voor toekenning van terugwerkende kracht 'kan zijn de noodzaak tot plotselinge invoering van een nieuwe regeling om te voorkomen dat burgers

61. Artike XIV lid 2 hidt:" Artikel 9 wijfe lid van de Wet op de studiefinanciering is niet van toepassing op degene die beschikt over een verlenging van de inschrijvingsduur die op grond wan het eerste lid haar geldigheid behoudt.

62. Derde nota van wijzigingen, nr. 21 . Met deze wijziging wordt tegemoetgekomen an de amendementen van de leden Franssen em Lansink (nr. 13) en van Nuis (nr. 20).

63. $20469 \mathrm{~B}, \mathrm{p} .5$ ondler punt 6.

64. Datizlide argument word ook al in de Mx T (nr. 3, p. 6/7 en 18) gegeven. 
maatregelen treffen waardoor die regeling haar beoogde effect ontbeert of zelfs een tegengesteld effect sorteert. Alsdan kan de grensdatum wan de terugwerkende kracht samenvallen met de datum waarop de inhoud van de ontwerpregeling bekend is gemaakt'. Tevens wijst de regering op her auditorenfonds.

Die datum van 17 september 1987 komt niet erg sterk over. Wat is de bindende kracht van het bekendmaken van het beleid ter gelegenheid van de indiening wan ontwerpbegroting als er ter zake nog helemaal geen wetsvoorstel is?' Dat is pas op 29 februari 1988 ingediend bij de Tweede Kamer.

In het voorlopig verslag wordt zeer scherpe kritiek geleverd door vrijwel alle partijen op de terugwerkende kracht van artikel XIV en de beperking wan de inschrijvingsduur op grond van reeds genoten studiejaren ${ }^{65}$

In de $\mathrm{MvA}^{66}$ gaat de regering onder het kopje 'Terugwerkende kracht" unitgebreid in op de bezwaren die door de Tweede Kamerfracties naar voren zijn gebracht.

De regering houdt vast aan de datum van 15 september 1987 in verband met de financiële consequenties. Inzake de bezwaren van een aantal fracties tegen de onbeperkte terugwerkende kracht met betrekking tot reeds in het hoger onderwijs verbruikte inschrijvingsduur wat voor veel studenten onaanvaardbare gevolgen oplevert, merkt de regering - die ter zake liever spreekt van 'in beschouwing nemen' dan 'terugwerken' - op, dat bedoelde groep studenten reeds in het verleden heeft geprofiteerd van tegen een sterk gereduceerde prijs door de gemeenschap verstrekte voorzieningen. 'Het komt dan ook rechtvaardig voor dat deze groep voortaan niet meer rechten ontvangt dan de huidige studentengeneratie. In verband met gewekte verwachtingen is well een overgangsmaatregel getroffen ten behoeve van degenen die na afgestudeerd te zijn in het andere subsysteem met een tweede studie zijn begonnen.' De regering doelt hier op artikel XII. In de terminologie van art. 74 Aanwijzingen voor de wetgevingstechniek, is er geen sprake van terugwerkende kracht, maar van exclusieve werking. Het materiële effect is echter hetzelfde. In het eindverslag hand haven de fracties hun bezwaren. ${ }^{67}$ In de nota naar aanleiding van het eindverslag ${ }^{68}$ betreuren de ondergetekenden dat hun overwegingen niel op algemene bijval kunnen rekenen. De bewindspersonen merken op dat zich uit literatuur en jurisprudentie enige toetsingspunten laten distilleren voor beoordeling van de mate van aanvardbaarheid van terugwerkende kracht. Deze toetsingspunten kunnen als volgt worden omschreven:

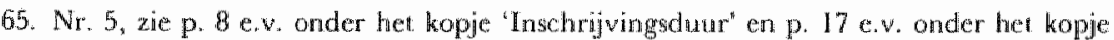
"Terugwerkende krachl",

66. Nr.6, p. 21 e.v.

67. Nr. 8, p. 19 e.v.

68. $\mathrm{Nr} .9$, p. $38 \mathrm{e} . \mathrm{v}$. 
a. er moeten zeer klemmende redenen zijn voor terugwerkende kracht, aan de maatregel moet derhalve een deugdelijke belangenafweging ten grondslag liggen:

b. de maatregel dient niet dan in beperkte mate terug te werken;

c. de inbreuk op gerechtvaardigde verwachtingen moet voorzienbaar zün geweest, moet derhalve aan belanghebbende op de een of andere wijze bekend zijn. Dit beperkt de inbreuk op het beginsel van de rechtszekerheid;

d. het feit van de terugwerkende kracht moet expliciet uit de desbetreffende regeling biljken, met vermelding van het tijdstip van terugwerking;

c. de inbreuk op bestaande rechten mag niet te groot zijn;

f. zo mogelijk worden nadelige gevolgen van de terugwerkende kracht verzacht door overgangsmaatregelen.

Naar het oordleel van cle regering kan het wetswoorstel deze toetsingspunten doorstaan.

ad a: De ondergetekenden zien zich geplaatst woor de noodzaak van een stringent bezuinigingsbeleid. Het belang van de besparing weegt op tegen de, met verzachtende maatregelen omgewen, terugwerkende kracht. ad $b$ : Erkend wordt dat de maatregel vrij ver terugwerkt. Daaraan valt evenwel niet te ontkomen omdat het financiële beleid voor 1988 nu eenmaal op zijn laatst bij gelegenheid wan de indiening van de ontwerp-Rijksbegroting wordt bekend gemaakt.

ad c: In de ingediende ontwerp-Rijksbegroting was ook reeds voor 1988 voorzien in de mede door de terugwerkende kracht te bereiken bezuiniging van 165 miljoen. Voorts is zeer kort daarop een concept-wetsvoorstel in de openbaarheid gebracht (6 oktober 1987) dat de terugwerkende kracht in detail regelde en ook expliciet toelichtte.

ad d: Artikel XIV regelt de terugwerkende kracht, met vermelding van de datum van 15 september 1987.

ad en f: De inbreuk kan in zijn nadellige effecten beperkt blijven door enige in het wetsvoorstel vervatte verzachtende maatregelen: incidenteel is voorzien in aanvulling van de inschrijvingsduur van degenen die voor de beoogde datum van inwerkingtreding van dit wetsvoorstel een aanvang hebben gemeakt met een tweede studie in het andere $\mathrm{HO}$-systeem dan watrin zij eerder zijn afgestudeerd. Voorts is structureel voorzien in cen ondersteuningsfonds (auditorenfonds) ten behoeve var studenten wier inschrijvingsduur is werbruikt en die als gevolg daarvan hun studie niet zouden kunnen afmaken. Hiermee kan naar de mening van de ondergetekenden worden gesproken van een per saldo beperkte inbreuk op de belangen van betrokkenen.

De overwegingen wan de regering zijn toegespitst op de problematiek van 
de verlenging van de inschrijvingsduur wegens bijzondere omstandigheden (artikel XIV).

Inzake de terugwerkende kracht met betrekking tot de reeds verbmuikte inschrijvingsduur merken de ondergetekenden op dat het redelijk is 'dat degenen die in het verleden zonder goed gevolg zes jaar hoger onderwijs hebben gevolgd, niet alsnog extra inschrijvingsduur als student tegen het lage collegegeldtarief word toegekend. Gebeurt dat wel, dan worden deze studerenden bevoorrecht boven degenen die vallen onder de bestaande en woorziene inschrijvingsduurbeperkingen en evenmin in staat zijn hun studie als student met goed gevolg af te ronden en dat dus als auditor moeten doen'.

Dit is wel een hele curieuze redenering van de bewindspersonen. Omdat de studenten het in de toekomst slechter krijgen, moeten de studenten die al een poosje studeren het ook maar slechter krijgen. Maar dat is nu juist waar het beginsel van de terugwerkende kracht zich tegen verzet.

Zoals gezegd geeft de regering het verzet pas op tijdens de mondelinge behandeling in de Tweede Kamer. De regering kon moeilijk anders ondat. evident was dat anders amendementen zouden worden aangenomen. Artikel XIV wordt in dier voege gewijzigd dat na inschrijvingsdur moet worden toegevoegd 'verleend' en de zinsnede 'voor zover het betreffende verzoek is ingediend voor 15 september $1987^{\prime}$ komt te vervallen. ${ }^{69}$ In artikel 35 vijfde lid WWO worden de termijnen verlengd tot drie jaar (voor voltijders) respectievelijk vier jaar en zes maanden (voor deeltijders). ${ }^{70}$ Over artikel 34 lid 4 WWO wordt met geen woord gerept en ook later komt dit artikellid niet meer aan de orde. Op 21 juni wordt er gestemd in de Kamer. De fracties van PvdA, D66 en PPR stemmen tegen hel wetsvoorstel, de overige fracties vóór, zodat het is aangenomen. ${ }^{71}$

Uit het voorgaande kan geconcludeerd worden dat, all werd er in de loop van het wetgevingsproces verscheidene malen op gewezen dat het meetellen van reeds verbruikte inschrijvingsduur in het andere subsysteem studenten voor grote problemen kon platsen, de wetgever niet onderkend heeft dat artikel 35 lid 4 WWO strijd met het elementaire beginsel van de rechtszekerheid opleverde, althans in de ogen van de Haagse rechtbankpresident en van de Hoge Raad, hoewel deze laatste daar geen consequen* ties aan kon verbinden. Integendeel, de opvatting van de regering was dat studenten die de eerdere studie niet met succes afgerond hadden, dat aan zichzelf te wijten hadden.

Men mag ervan uitgaan dat de wetgever niet opzettelijk in strijd zal

69. Zic noot 62 .

70. Met deze wijging word tegemoet gekomen an het amendement van de leden Lavin en Franssen $(\mathrm{nr} \cdot 16)$ )

71. Hand. TK 1987-1988, p. 91-4960. 
handelen met Grond wet of ongeschreven rechtsbeginselen. Het valt echter niet uit te sluiten dat dit wel eens gebeurt, zoals het Harmonisatiewetarrest laat zien. Dan rijst vanzelf de vraag of er niet een rechter moet zijn die de constitutionaliteit van de wet kar toetsen, zelfs als het zou gaan om een entkel incident.

Ik betwijfel echter of het om een enkel incident gaat en vraag me af of er niet iets structureel mis is met het wetgevingsproces. Ik kom daar straks op terug, maar geef eerst nog twee voorbeelden van recente wetgeving war een en ander op aan te merken is.

Op 27 december 1988 heeft de Eerste Kamer vergaderd over de zogenaamde Sofiwet. ${ }^{72}$ Het is uiterst ongebruikelijk te vergaderen tussen kerst en oud en nieuw. De regering had de Eerste Kamer onder druk gezet dit wel te doen, omdat niet tijdige behandeling van het Soffwetsvoorstel belangrijke gevolgen kon hebben. De oppositie wilde geen gevolg geven aan deze druk en was alwezig. Men wilde geen verantwoordelijkheid dragen woor haastwetgeving. Staatssecretaris De Graaf ${ }^{73}$ merkt in de Eerste Kamer op dat het redelijk is dat de Eerste Kamer niet wil vergaderen tussen kerst en oud en nieuw. De Graaf acht het onbevredigend dat een substantieel deel van de Eerste Kamer niet aan het debat deelneemt en zelfs niet aanwezig is, terwijl hem bekend is dat de oppositie instemt met de doelstelling van het wetsvoorstel. Maar aan de andere kant is hij blij dat die dag tot afronding gekomen kan worden.

Het niet afwerken van het wetswoorstel zou een groot risico in zich bergen dat de uitvoering van de verzekerdenadministratie met een jaar zou worden vertraagd. Vertraging zou de belastingoperatie in 1990 op het spel kunnen zetten, aldus de staatssecretaris.

Het voorstel wordt in de Eerste Kamer met algemene stemmen aangenomen. Er word door allerlei sprekers gemopperd over vergaderen tussen kerst en oud en nieuw, maar niemand trekt conclusies uit het feit dat de oppositie afwezig is. Ja, dit komt zelfs afgezien van de opmerking van de staatssecretaris, helemaal niet aan de orde in het debat. $\mathrm{Nu}$ kan het natuurlijk niet zo zijn dat een minderheid in de Eerste Kamer om puur partijpolitieke redenen een behandeling van een wetsvoorstel kan vertragen, maar zo lag het, dunkt me, in casu niet. Indien een minderheid goede argumenten heeft niet tot haastwerk te willen overgaan, dan dient de meerderheid daarmee rekening te houden. Ik acht de behandeling van het wetswoorstel buiten aanwezigheid van de oppositie een dieptepunt in de parlementaire geschiedenis. Op zijn minst had er een discussic moeten

72. Hand. EK 1987-1988, 20 854, Stb. 1988, 655. Zie over deze wet H. Frankena, Hoe wìs is de weg nat Solia?, NJCM 1989, p. 281 e.w.

73. Hand EK 1988-1989, p. 14-591 e.v. 
plaatswinden over de reden wan afwezigheid en of daar al dan niet consequenties uit getrokken behoorden te worden.

Op vrijdag 9 december 1988 stelde de Hoge Raad in een aantal arresten ${ }^{74}$ vast dat de opvang van niet in Nederland toegelaten vreemdelingen op de luchthaven Schiphol, zoals die tot dan toe plaats vond en warbij de vreemdeling verplicht werd zich hangende de beslissing over zijn toelating of verwijdering, op te houden in het centrum Schiphol-oost, met zodanige ruimtelijke en sociale beperkingen gepaard gaat dat zij moeten worden aangemerkt als vrijheidsbeneming in de zin van artikel 15 Grondwet onderscheidenlijk vrijheidsberoving in de zin van artikel 5 EVRM, zonder dat zulks uitdrukkelijk door de wet wordt toegestaan.

De formele wetgever ontwikkelt een verbluffende snelheid om die formeel-wettelijke grondslag te realiseren. ${ }^{75}$ Op maandag 12 december 1988 adviseert de Raad van State. Het nader rapport is gedateerd op 13 december 1988. Indiening bij de Tweede Kamer vindt plaats op 13 december \988. De plenaire behandeling door de Tweede Kamer vindt plaats op 15 december. De Eerste Kamer laat zich ditmaal wat minder onder druk zetten. Behandeling vind plaats op 10 en 17 januari 1989.

Ik kan over deze gang van zaken kort zijn. Damen en Hoogenboom hebben deze gang van zaken diepgaand geanalyseerd in het $\mathrm{NJB} .^{76} \mathrm{Zij}$ wijzen op een aantal staatsrechtelijke nova. De Raad van Ministers heeft niet beraadslaagd en besloten over her wetsvoorstel (art. 4 lid 2 onder a, Reglement van Ordle voor de Raad van Ministers). Aan de ministerraad waren reeds eerdler de hoofdlijnen van de ten departemente levende gedachten voorgelegd. Op basis daarvan waren de bewindspersonen van Justitie gemachtigd zo nodig een wetsvoorstel in te dienen. ${ }^{77}$ De Raad van State heeft niet in pleno vergaderd in het weekend van 10 en 11 december 1988. Al eerder was het wetswoorstel informeel aanhangig gemaakt. De plenaire raad heeft een machtiging gegeven aan de rapporteur om na binnenkomst van de officiële adviesaanvraag de zaak af te doen aan de hand van de al bestaande stukken.

74. Zie MvT bij TK 1988-1989, 20972, wijziging van de Vreendelingenwet (werzekering grensbewaking), p. 1. Genoemd worder de zaken Shat/Shoku (13631), Staal/Mehra (13513) en Staat/Vown (13514). Eenafschrift van Staat/Mehra is in de bibliothek vari de Tweede Kamer ter inzage gelegd. Dit arrest is gepubliceerd in RvdW 1988,216 (werkort in NJB 1989, p. 26/27).

75. Zie het in noot 74 genoende wetswootstel.

76. LJ.A. Damen en T. Hoogenboom, $\mathrm{Na}$ 'confectierechtspraak' nu ook 'confechiewetgeving? $?$ ? JB $1989,145 \mathrm{e} *$.

77. Zie Damen/Hoogenboom, (noot 76) p. 147 en MvA EK 1988-1989, nr. 1136, p. 11. 
De Tweede Kamer heeft volstaan met een voor alle leden toegankelijk mondeling overleg in plaats van een schriftelijke voorbereiding. 9.79

Zijn deze voorbeelden incidenten of zijn zij symptomatisch voor het wetgevingsproces? Ik vrees het laatste. Maar zelfs al zouden het incidenten zijn, ook dan rijst de vraag wat er aan gedaan kan wordlen. Alvorens te concluderen tot opheffing van de onschendbaarheid var de wet, kan men zich de vraag stellen of het wetgevingsproces niet zodanig gewijzigd kan worden dat het (weer) voldoende waarborgen geeft voor constitutioneel handelen door de wetgever. Ik zie daarvoor geen mogelijkheden. Altijd zal de politieke meerderheid, als zij dat wil, haar zin kunnen doordrukken.

\section{CONSTTUUTIONELE TOETSING $?^{80}$}

Alvorens argumenten voor opheffing van de onschendbaarheid van de wet ten opzichte van de Grond wet te bespreken, hetgeen uiteraard gepaard zal dienen te gaan met Grondwetswijziging, zal ik eerst nog eens kort de argumenten tegen op een rijtje zetten.

Traditionele argumenten om de onschendbaarheid van de wet te handhaven zijn:

- de onschendbaarheid past in de Nederlandse traditie;

- het parlement behoort het laatste woord te hebben;

- het wetgevingsproces kent voldoende waarborgen;

- de onafhankelijkheid en het gezag van de rechter komen teveel in gevaar indien hij zich męt politieke kwesties moet bezighouden.

Argumenten die pleiten voor de mogelijkheid van toetsing van de formele wet aan de Grond wet zijn:

- Het is inconsequent indien Nederlandse formele wetsbepalingen door de Nederlandse rechter wel buiten toepassing kunnen worden gelaten wegens strijd met een ieder verbindende verdragsbepalingen en niet wegens strijd met de Grond wet. Het is een logische stap verder de rechter de bevoegdheden te geven ook de (toepassing van de) formele wet te laten toetsen aan de Grondwet.

78. Zie TK 1988-1989, 20972 nir. 4, Verslag van een mondeling overleg nevens verslag.

79. Vermeldensward is nog dat de MVA a a de EK eerst enkele uren voor het geplande deban beschikban was. Zie Damen/Hoogenboom, p. 149.

80. P.B. Cliteu, Argumenten voor en tegen constitutionele toetsing, NJB 1989 , p. $1369 \mathrm{e.v}$. notrnt als principible argumenten tegen: het democratie-argument, het rechtszekerheidsarguthent en he triasargument. De pragmatsche argumenten tegen toetsing zijn: bet traditic-argument, het argument van rechtenlike incompetentie en het argument dat verandering legitimatio behoeft. De argumenten voor toetsing 2 ijn: het verdragsa rgument, de: veranderde bouding ten oprichte van de wet, her argument van het primaat van de grondrechen th bet argument van de falende wetgewer. Zijn canclusie is dau de argumenten tegen toersing niet doorshggevend zijn. 
- De rechter toetst ieder algemeen verbindend voorschrift aan een hoger algemeen verbindend voorschrift. Waarom zou de wet in formele zin daarop een uitzondering moeten zijn?

- Hoewel het formele wetgevingsproces vele waarborgen bevat, is het toch uiteindelijk de politieke meerderheid die de beslissing neemt. Al naar gelang de tijdgeest zal de politieke meerderheid zich meer of minder gelegen laten liggen aan de Grondwet en aan algemene rechtsbeginselen. Recente wetgeving laat zien dat de wetgevingsprocedure wel eens gebruikt wordt om de standpunten van de regering door te drukken. De noodzaak tot financiële bezuinigingen lijkt vaak zwaarder te wegen dan het in acht nemen van rechtsbeginselen. ${ }^{81}$

- De rechter is meer geschikt en ook meer geneigd om individuele rechtsposities en die van minderheden veilig te stellen. ${ }^{82}$

- Constitutionele toetsing leidt niet tot cen rechtersstaat in de zin dat de rechter boven de wetgever komt te staan. De rechter bewalkt de rechtsstatelijke randvoorwaarden. Hij treedt in de letterlijke zin op als grensrechter. Daarbinnen heeft de wetgever een uitermate grote beleidsvrijheid. Gedacht vanuit een systeem van checks and balances verdient het de voorkeur dat de bewaking van de randwoorwaarden gebeurt door een ander orgaan dan de wetgever, namelijk de rechter.

- In plaats van een trias is er heden ten dage eerder sprake van een "duas". Tegenover het machtsblok wetgever-regering dient een sterke rechter te staan, die ook de formele wetgever moet kunnen controleren.

De argumenten vóór opheffing van de onschendbaarheid der wet zijn naar mijn mening vrij overtuigend. Het is gewenst dat de Grondwetgever zich opnieuw bezint op het vraagstuk van de constitutionele toetsing. Als besloten wordt tot invoering van constitutionele toetsing rijst vervolgens de vraag hoe één en ander geoperationalliseerd moet worden.

\section{OPERATIONALISERING CONSTITUTIONELE RECHTSPRAAK}

Als men besluit tor ophelfing van de onschendbaarheid der wet en derhalve de wet dan wel de toepassing daarvan ${ }^{83}$ wil laten toetsen aan de Grondwet, rijst de vraag waaraan precies getoetst dient te worden, welke acties

81. Zie over de verhouding financièle normen en rechunomen A.F.M. Brenninkmever,

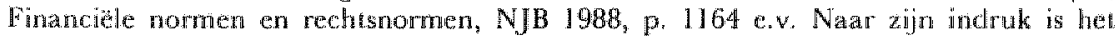
wetgewingsinstrumentarium nog onvoldoende ontwikeld om te komen tot eetn verantwoorde afstemming van rechtsnormen en financièle normen. Nadere bostudering iv dringrend ryodig.

82. Zie voor hoe de Amerikaanse rechter het gelijkheidsbeginsel hanteen Koopmans, Vergeljkend publiekrecht, Deventer 1986 , tweede druk, p. 56 c.v.

83. Zie over dat onderscheid noor 26. 
mogelijk gemaakt moeten worden en door wie (iedere rechter of een speciaal daartoe ingestelde rechter) die toetsing moet plaatsvinden.

In navolging van de Proeve en de commissie Cals-Donner wordt vaak gepleit voor toetsing aan de (klassieke) grondrechten. Die benadering is in zoverre begrijpelijk dat daarmee de inconsistentie wordt opgeheven, dat nu wel aan eer ieder verbindende verdragsbepalingen mag worden getoetst maar nilet aan de Grondwet. Met deze oplossing wordt echter weer een mieuwe inconsistentie gecreëerd. De rechter mag de wet slechts toetsen aan een deel van de Grondwet. Dat lijkt niet goed verdedigbaar. Hoewel niet ontkend kan worden dat toetsing aan hoofdstuk I Grondwet veel vuurwerk kan opleveren ${ }^{84}$, is met name de mogelijkheid van toetsing aan de procedure van wetgeving ook belangwekkend. ${ }^{\text {.5 }}$ De hiervoor geanalyseerde wetgeving geeft aan dat de constitutionele rechter hier veel aanknopingspunten heeft voor onverbindendverklaring. Bovendien is van deze procedurele toetsing het grote voordeel dat de rechter terugverwijst en dat de wetgever zijn werk opnieuw kan doen. Ook op andere onderdelen van de Grondwet kan toetsing nuttig zijn, zoals inzake de positie van lagere rechtsgemeenschappen; hoewel de Grondwet nawwelijks echte waarborgen geeft aan die rechtsgemeenschappen. ${ }^{86}$

Een volgende vraag die rijst is of de constitutionele rechter - wie dat dan ook is - de bevoegdheid zou moeten krijgen om formele wetten behalve aan de Grondwet ook aan ongeschreven rechtsbeginselen te toetsen. ${ }^{3 / 2}$ Die mogelijkheid openen is nog weer een fundamentele stap verder. Men kan de Grondwet zien als de wil van de grondwetgever, die wordt geïnterpreteerd. Bij toetsing aan rechtsbeginselen wordt geabstraheerd

84. Ik wijs bijwoorbeld op de dissertatie van A.Q.C. Tak, Met huisrecht, Hoenderloo 1973. Hij conchudert dat van de ruim 200 door hem onderzochte wettelike bepalingen alleen de Mijnwet 1903 geacht kan worden geheel te voldoen aan de eisen van het (toenmalige) art. $172 \mathrm{Crw}$.

85. CI. HR 27 januari 1961, NJ 1963, 248 (van den Bergharrest).

86. In de Verenigde Staten van Amerika en de Bondsrepubliek Duitsland was cen belangrike ratio woor invering wan constitutionelte toesing de bewaking van de competentiealbakening tusen bondstat en deelsquten.

87. De Hoge Rad acht het op dit moment op grond van de huidige Grondwet niet mogelijh, mat shir nier uit dat later to die toetsing wordt overgegzan. In de literatutur hebbuen Alkema (Een meerkeuzetoets, oratic Leiden 1985) en Kortmann (De Grondwetsherzieningen 1983 en 1987, tweede druk, Deventer 1987, p. 334) bepleit dat toetsing aan rechtsbeginselen on grond van de huidige Grondwet mogelijh moet zijn. Tegenover deze opwathingen stat het argument contra wan Mok (Rechterlijke toetsing van wetgeving, Recht op scherp, Dukbunde, Zwolle 1984), dat het absurd is niet dat niet getoetst zon nogen worden an in de Grondwet gepositiveerde nechtsbegimseler, maar wel aan ongeschreven rech tsbeginselen. $\mathbb{R}$. E. de Winter reageert op Mok dat dat inderlaad absurd is, maar De Wintel acht het even zeer absurd dat in het door Mok genoemde geval /gelijkheidsbeginsel) wel krachens art. 94 Orw getoetst mag worden aan art. 26 Intermationaal verdrag inzake politieke en burgerrechten. En toch is dall geldend recht, VAR XCVI 1987, p. 251, nool 61 . 
van de wil van de grondwetgever en dat versterkt de positie van de constitutionele rechter zeer. Anderzijds kan men ook zeer goed verdedigen dat ongeschreven rechtsbeginselen aan onze Grondwet ten grondslag liggen. Bovendien is het vaak enigszins willekeurig of een rechtsbeginsel gepositiveerd is in de Grondwet of niet. Soms is een rechtsbeginsel vanwege zijn evidentie niet opgenomen in de Grondwet, zoals - zie het Harmonisatiewet-arrest - het rechtszekerheidsbeginsel. Ook worden, althans in de regel, andere algemeen verbindende voorschriften dan formele wetgeving aan ongeschreven rechtsbeginselen getoetst. ${ }^{88}$

Dit alles pleit ervoor ook toetsing aan ongeschreven rechtsbeginselen mogelijk te maken. Wellicht is wel een beperking gewenst in de zin dat het moet gaan om fundamentele rechtsbeginselen die aan onze rechtsorde ten grondslag liggen. ${ }^{89}$

Vervolgens moet de vraag beantwoord worden hoe de verhouding ligt tot het internationale recht. Het opwerpen van deze vraag is alleen relevant indien men kiest voor een speciaal daartoe ingestelde constitutionele rechter. Iedere rechter is immers op dit moment al bevoegd de toepassing van de formele wet te toetsen aan een ieder verbindende verdragsbepalingen. Als men kiest voor de mogelijkheid van toetsing aan ongeschreven rechtsbeginselen ligt ook toetsing aan rechtstreeks werkende verdragsbepalingen voor de hand. Als men dat niet mogelijk zou maken, zal de speciaal daartoe ingestelde constitutionele rechter de in de verdragen neergelegde rechten al gauw als ongeschreven rechtsbeginsellen beschouwen. Dit is misschien een beetje flauw, maar er zijn meer argumenten. Zoals al is opgemerkt geeft artikel 94 Grondwet nu al aan iedere rechter de bevoegdheid

88. Niet altijd. Zo toetst de ARRvS, in tegenstelling tot CBB en CRvB, algemeen verbindende voorschriften niet aan rechtsbeginselen. De administratieve rechters kunnen algemeen verbindende voorschriften alleen bij exceptie aan hogere voorschriften en rechtsbeginselen toetsen. De burgerlijke rechter kan dat ook rechtstreeks, op grond van een artikel 1401 BW-acrie. De burgerlijke rechter toetst daarbij ook aan ongeschreven rechtsbeginselen. Zire HR 16 mei 1986, AB 1986, 574 m.nt. PwB (Landbouwvliegers-arresit).

89. Het spreek vanzelf dat indien het de ongeschreven regels van het parlementaire stelsel betreft, de toetsing uitermate terughoudend dient te zim. Of de constitutionele rechter überhaupt kan toekomen aan toetsing van die regels hange af van de acties die mogelijk gemakt worden. Ook anderszins kar terughoudendheid of zells onthouding gewensi ziju. Vergelijk de "political question" doctrine in de VS en de zogenamde "actes do gouvernement" in Frankrijk.

De constitutionele rechter mag zich in ieder geval niet zo opstellen als Boudin meende dat dat in 1932 in de VS het geval was: "It is a canon of constitutional "interpreiation" well-recog. nized by the oflicial theory, that before a statute can be "disregarded" its conflict with the Constitution must be clear and beyond doubt. (...) Unfortunately, the official theory does not at all tally with the facts. The actual practice of the courts is to declare any law unconstitutional of which they strongly disapprowe, whatever the reason of such disapproval, and quite irrespective of the actual provisions of the Constitution, which very frequently says nothing at all on the subject..." in: Morris R. Cohen en Felix $\mathbf{S}$. Cohen, Jurisprudence and legal philosophy, Boston/Toronto 1951, p. $881-882$. 
wetten aan ieder verbindende verdragsbepalingen te toetsen. Het zou dan wel merk waardig zijn indien een speciaal daartoe ingestelde constitutionele rechter dat niet zou mogen. Bovendien kan men verdedigen dat, gelet. op ons monistisch systeem, de een ieder verbindende verdragsbepalingen deel ustmaken van onze nationale rechtsorde. Het gevaar bestaat dan wel dat de Nederlandse constitutionele rechter overruled wordt door 'Straatsburg', maar dat is nu cenmaal 'all in the game". 90 Die mogelijkheid van overruling zou overigens sterk verminderd worden indien de Nederlandse rechter prejudiciële vragen zou kunnen stellen aan de rechter in Straatsburg. Dat vereist overigens wel wijziging van het EVRM. ${ }^{91}$

\section{Wit moet de constitutionele rechtspraak gaan uitoefenen?}

We kunnen kiezen uit drie, strikt genomen eigenlijk uit twee mogelijkheden, en wel uit het Franse model, het Westduitse model, het Amerikaanse model of varianten daarvan.

In Frankrijk is er eigenlijk geen sprake van echte constitutionele rechtspraak omdat de Conseil Constitutionnel toetsk vóordat de wel wordt afgekondigd. Organieke wetten moeten worden voorgelegd aan de Conseil Constitutionnel; gewone wetten, behoudens referendaire, kunnen voor hun afkondiging aan de Conseil ter toetsing worden voorgelegd door de president, de minister-president, de voorzitters van de Assemblé en de Senaat, alsook zestig leden van een van beide kamers. ${ }^{92}$ De president en de beide kamervoorzitters benoemen elk drie leden. Oud-presidenten zijn van rechtswege lid. Kortmann merkt op dat op de benoemingen van diverse zijden is aangemerkt dat deze te zeer van politieke aard zouden zijn. ${ }^{93} \mathrm{De}$ meerderheid van de leden komt voort uit kringen van de regeringsmeerderheid. De zittingsduur is negen jaar. On de drie jaar treedt cen derde van de leden af. Het. Franse systeem lijkt voor Nederland aantrekkelijke kanten te hebben. De nadelen die een al te politieke samenstelling met zich brengt, kunnen voorkomen worden. Men zou bijvoorbeeld de president van de Hoge Raad en de vice-voorzitter van de Raad van State kunnen betrekken bij de benoeming. Een ander nadeel is echter moeilijker te verhelpen. Uit een oogpunt van rechiszekerheid zou het het beste zijn indien iecler wetsontwerp getoetst zou worden. Dat zou echter een fysiek te zware taak worden voor een constitutioneel college. Bovendien kan men dan al helemaal niet meer spreken van een rechterlijk college. Typerend voor een

90. Zo achi ik het uitemate warschinhlijk da een Nederlandse constitutionele rechter, als dewe in 1985 had bestan, het Kronberoep constitutioneel had geacht.

91. Zoals bujwoorbeeld bxpleit door E. A. Alkema, "Toepassing van de Europese Conventie woor de Rechten van de Mens", preadvies voor de Vereniging voor de vergelijkende siudie wan het recht wan Belgiè en Nederland, Zwolle 1985.

92. Zie Kormann in "Hef statsmecht van de landen van de Europese Gemerenschappen', Deventer 1981, eerste druk, p. 227-228; derde druk, Deventer 1988, p. 212-216.

93. A.w. noot 92 , ecrste druk, 1981, p. 225; derde druk, 1988, p. 213. 
rechter is dat hij geadieerd moet worden. Indien men echter de toetsing afhankelijk zou maken van bijvoorbeeld het initiatief van een bepaald aantal kamerleden of de regering, bestaat het gevaar dat dit gaat gebeuren om alsnog het politieke gelijk te behalen en de politieke strijd te verlengen. Bovendien bestaat dan het gevaar dat wetsontwerpen die niet ter toetsing worden voorgelegd, toch inconstitutioneel kunnen zijn. Dat is dan echter niet meer te verhelpen. Kortom, a an het Franse model zitten veel haken en ogen. Het is niet waarschijnlijk dat een dergelijk systeem onze problemen voldoende zou oplossen. ${ }^{94}$

In de Verenigde Staten acht iedere rechter het tot zijn bevoegdheid te horen wetten aan de Grondwet te toetsen, zowel op deelstaatniveau als op federaal niveau. ${ }^{95}$ Die toetsingsbevoegdheid is op verschillende manieren te verklaren. In de eerste plaats vanwege de federale structuur van de $V S_{\text {, }}$ in de tweede plaats vanwege de grondwettelijke competentic-afbakening tussen wetgevende en uitvoerende macht en in de derde plaats vanwege de niet homogene samenstelling van de bevolking - minderheden dienen beschermd te worden ${ }^{96}$ Koopmans wijst nog op een andere, zij het betwiste mogelijkheid. ${ }^{97}$ In talrijke Common-wealth-landen bestaat constitutionele toetsing in de een of andere vorm. De historische verklaring is dat in de koloniale $t$ jjden wetgeving van de koloniën als subordinatie legislation werd beschouwd die door de Privy Counsil te Londen aan de Britse wet werd getoetst.

Invoering van het Amerikaanse systeem zou voor de Nederlandse verhoudingen wel een erg dramatische omwenteling betekenen. ${ }^{98}$ Het zal voor velen even wennen zijn indien de kantonrechter te Groenlo een formele wetsbepaling opzij kan zetten wegens strijd met de Grondwet. Bovendien

94. A.H.N. Dölle (in Dölle/Engels, Constitutionele rechtspraak, Groningen 1989, p. 74) kiest voor een lichte vorm van prevertieve toetsing. Hij denkt an de $H R$ of een apart te constitueren vaste commissie ex art. $79 \mathrm{Grw}$ warin de presidenten van de HR. ARRS, CRvB e.d. zitting hebben. De Raad van State blijf zijn adviserende rol wat betreft de constitutiona liteit van wetsont werpen behouden. Deze oplossing lijkt mij niet zo erg galant tegenover de RVS. Bovendien vwag ik me af wat de HR of de commissie zoved meer zouden bieden dan watt de RuS (in potentie) kan bieden.

95. Reeds in 1803 achte het Amerikanse Supreme Court zich bevoegd en federale wet. aan de Grondwet te roetsen (Marbury w. Madison).

96. T. Koopmans, Vergelijkend publiekrechi, Deventer 1986, tweede druk, p. $19 \varepsilon . \mathrm{v}$.

97. Engels (in Dölle/Engels, Constitutionele rechtspraak, Groningen 1989, p. 75 c.w.) pleit voor het schrappen van de woorden 'wetten en' uit art. $120 \mathrm{Grw}$, met andere woorden hij kiest voor de oplossing dat iedere rechter de formele wett moet kunnen toetsen aan de Grw. Naar zijn mening kan de keuze voor een opening naar rechterlijk toetsingsrecht minder voor de hand liggen indien zulks gepaard gat met al te rigoreuze institutionele wizigingen en ingrepen in bestaande competenties. Naar mijn mening echter is het sehrappen wan de woorden 'wetten en' voor wat betreft de ingreep in bestaande competenties ingrijpender dan wanneer het toetsingsrecht wordt toegekend aan (een constitutionele kaner van) de HR.

98. A.w. p. 30 . 
gaat dan het oude argument van Buys inzake de rechtszekerheid een rol spelen.

Laat ons daarom eens kijken of onze oosterburen wellicht iets aantrekkelijkers te bieden hebben.

De Bondsrepubliek Duitsland kent een Bundeswerfassungsgericht dat is gevestigd te Karlsruhe. ${ }^{90}$ Evenals de VS kent de Bondsrepubliek cen federale structumr. ${ }^{\text {Do }}$ Een belangrijk argument voor invoering van constiwutionele rechtspraak waren de ervaring met het Hitler-regime.

Het Bundesverfassungsgericht (BVerfG) heeft verschillende taken. Ik noem slechts die taken die voor ons in Nederland het meest interessant zijn ${ }^{101}$, nl.:

a. konkretes Normenkontrol.lverfahren. Toetsing in concreto van de grondwet. Slechts de geadieerde rechter kan de zaak bij hell BVerfG aanhangig maken door middel van het inroepen van een prejudiciële beslissing.

b. abstraktes Normenkontrollverfahren. Het betreft toetsing in abstracto, dat wil zeggen toetsing los van een concreet rechtsgeschil. Een zaak kan aanhangig worden gemaakt door de bondsregering, door een landsregering of door ten minste een derde van de leden waaruit de bondsdag bestaat.

c. beslissen naar aanleiding van Verfassungsbeschwerden, dat will zeggen op grond van particuliere klachten over grondrechtenschending.

Het voordeel voor ons van het Westduitse systeem boven het Amerikaanse is, dat er vrij snel rechtszekerheid bestaat over de constitutionaliteit van wetten. Men behoeft niet in drie instanties te procederen voor er een (eind) uitspraak is. Bovendien zal een speciaal gerechtshof, bezet met topjuristen, eerder gezag verwerven, zowel van de wetgever als van de bevolking. In de Nederlandse verhoudingen zou men kunnen denken aan een bijzondere kamer van de Hoge Raad, waarbij ik er dan wel van uitga dat de administratieve gerechten worden geintegreerd in de rechterlijke machit. De vraag die dan rijst is of aan de leden van de constitutionele kamer andere benoemingseisen moeten worden gesteld dan aan de 'gewone' leden van de Hoge Raad? Ik meen van niet. Zo is bijvoorbeeld de jurisprudentie op het gebied wan de drukpersvrijheid grotendeels ontwikkeld door de strafkamer van de Hoge Raad, met name door het toetsen van gemeentelijke strafbepalingen aan artikel 7 Grondwet. De Afdeling recht-

99. Zie Koopmans, a.w. p. 61 e.v. en M.G. Burkens, De Bondsrepubliek Dutsland, in: Het staaisrechi van de landen van de Enropese Gemeenschappen, Deventer 1981, eerste druk; derde druk, Deventer 1988.

100. Op de Verfassungsgerichte van de Leinder ga ik miet nader in.

1.01. Burkens, a.w. p. 162 e.v. derde druk p. 153 e.v. 
spraak van de Raad van State heef zich bij deze jurisprudentie arangesloLen.

De strafkamer, maar ook de burgerlijke kamer op grond van onrechtmatige daadsacties, hebben dus al ruime ervaring met toetsing van allerlei bepalingen wit werordeningen aan Grondwetsbepalingen. Ik zie niet in waarom in geval van toetsing van formele wetsbepalingen aan de Grondwet er sprake zou moeten zijn van andere benoemingseisen. Overigens maakt artikel 118 lid 1 Grondwet, dat aan de Tweede Kamer een recht van voordracht geeft, het mogelijk dat ook de politieke achtergrond van kandidaat-leden meespeelt.

Het is mogelijk dat de constitutionele kamer, zeker in het begin, geen dagtaak zal hebben. Het lidmaatschap van die kamer kan gecombineerd worden met het lidmaatschap van een andere kamer.

Men kan erover discussiëren welke acties mogelijk gemaakt moeten worden. Dat zal ook trouwens nog nadere studie vergen. Een mogelijk gevaar van 'abstraktes Kontrollwerfahren' is dat politici de politieke strijd voortzetten voor de constitutionele kamer. De mogelijkheid van Verfassungsbeschwerchen lokt wellicht een zeer groot aantal acties uit. Men zou dan ook wellicht kunnen volstaan met 'konkretes Normenkontrollverfahren' oftewel de prejudiciële procedure.

Het wordt wel technisch ingewikkeld indien de constitutionele rechter - als dat mogelijk gemaakt zou worden; zie hiervoor - weer een preju“ diciële vraag zou moeten stellen aan het Europese Hof te Straatsburg. De kans dat hij dat zou moeten wordt minder, indien iedere rechter de bevoegdheid zou krijgen een prejudiciële vraag aan 'Straatsburg' te stellen. ${ }^{102}$ Aangezien krachtens art. 94 Grondwet iedere rechter bevoegd is de toepassing van formele wetsbepalingen te toetsen aan een ieder verbindende verdragsbepalingen, ligt het voor de hand ook iedere rechter bevoegd te maken prejudiciële vragen te stellen aan 'Straatsburg', zoals nu ook iedere rechter dat kan aan het Hof van Justitie te Luxemburg op grond van artikel $177 \mathrm{EEG}$-verdrag. Anclerzijds valt er ook wel iets voor te zeggen de constitutionele rechter exclusief bevoegd te maken inzake toetsing van de toepassing van formele wetsbepalingen aan een ieder verbindende verdragsbepalingen en inzake het stellen van prejudiciële vragen aan 'Straatsburg'. Het is immers niet logisch voor toetsing van wet aan Grondwet een constitutionele rechter exclusief bevoegd te maken, terwijl inzake toetsing van de toepassing van formele wetten an een ieder verbindende verdragsbepaling iedere rechter bevoegd is. Dit argument is analoog van toepassing op de verhouding formele wet - EG-recht.

$\mathrm{O}_{\mathrm{p}}$ dit moment is de precieze uitwerking echter niet van het grootste belang. De belangrijkste vraag is of men vóór de mogelijkheid van toetsing

102. Vergelijk ant. $177 \mathrm{EEG}$-verdrag inatke de bevoegdhe id van de rechter een prejudicièle vraag te stellen aan het Hof wan Justitie te Luxcmburg. 
aan in ieder geval de Grondwet is. Die vraag heb ik bevestigend beantwoord. De operationalisering kan dan het beste plaatsvinden door het instellen van een constitutionele kamer bij de Hoge Raad. ${ }^{103}$ Invoering wan constitutionele rechtspraak yornt een mooi sluitstuk op de reorganisatie van de rechterlijke macht die in de jaren negentig zal plaatsvinden.

Aan het eind vari mijn rede gekomen, stel ik het op prijs diegenen te bedanken die ertoe hebben bijgedragen dat ik aan deze universiteit als hoogleraar ben benoemd. Ik dank het College van Bestuur voor het in mij gestelde vertrouwen.

Mijn opleiding als jurist heb ik genoten aan de juridische faculteit van de Rijksuniversiteit Leiden. Het waren met name de zeer boeiende colleges van Koopmans die mijn belangstelling voor het staats- en bestuursrecht gewekt hebben.

Enkele jarren na mijn afstuderen had ik het voorrecht wetenschappelijk medewerker te worden bij de valkgroep staats- en bestuursrecht van de Rijksuniversiteit Utrecht. Daar trof ik een sfeer aan die optimaal was voor de wetenschappelijke beoefening van het staats- en bestuursrecht. Vele leden van die vakgroep hebben bijgedragen tot mijn verdere wetenschappelijke vorming. Ik hecht eraan in het bijzonder mijn promotor Steenbeek te noemen.

In Maastricht ben ik wederom terechtgekomen in een vakgroep waar het staats-en bestuursrecht met enthousiasme beoefend wordt. Ik stel mij veel voor van samenwerking met vakgroep en faculteit op het terrein van het onderwijs en onderzoek.

Na een aantal jaren voornamelijk bezig geweest te zijn met het vervaardigen van schriftelijk onderwijs verheugt het mij, dames en heren studenten, weer zelf onderwijs te kunnen geven. Het Maastrichtse systeem stelt zware eisen aan de zelfstandigheid van de student en het vereist een actieve houding.

$1 \mathrm{k}$ zal mijn uiterste best doen om ertoe bij te dragen dat uw studieverblijf in Maastricht een succes wordt.

Ik dank u voor uw aandacht.

103. Ook Hirsch Ballin en M. L.P wan Homen, Namens 1989, p. 19 e.v. bepheiten een vorm van geconcentreede constitutionele toetsing, bij voorkeur door aamsluiting te zocken bij de cassatierechrsprazk. Zir ook de noo van Hirsch Ballin bij het Harmonisatiewetarrest. AA 1989, p. 578 a.v. in he bijzonder p. 592 